\title{
Dynamic Corporate Risk Management: Motivations and Real Implications
}

Georges Dionne, corresponding author

Canada Research Chair in Risk Management HEC Montreal

3000, Chemin Cote-Sainte-Catherine, suite 4.454

Montreal (Qc) Canada H3T 2A7

georges.dionne@hec.ca

phone: 514-340-6596 fax: 514-340-5019

Jean-Pierre Gueyie

Department of Finance

University of Quebec in Montreal

C.P. 8888, succ. Centre-ville

Montreal (Qc) Canada H3C 3P8

gueyie.jean-pierre@uqam.ca

Mohamed Mnasri

Canada Research Chair in Risk Management

HEC Montreal

3000, Chemin Cote-Sainte-Catherine, suite 4.454

Montreal (Qc) Canada H3T 2A7

mnasri.mohamed@uqam.ca

8 August 2017

\begin{abstract}
We investigate the dynamics of corporate hedging programs used by US oil producers and examine the effects of hedging maturity choice on firm value. We find evidence of a concave relationship between hedging maturity and the likelihood of financial distress and oil spot prices. We further investigate the motivations of the early termination of outstanding hedging contracts. Using the essential heterogeneity approach, we evaluate the causal effects of hedging maturity on firm value. Marginal firm value increases with short-term hedging maturity. The causal effects vary across oil producers with different hidden attributes.
\end{abstract}

Keywords: Hedging maturity; Early termination of contracts; Firm value; Heterogeneous treatment effects; Essential heterogeneity models; Oil industry.

JEL classification: D8, G32. 


\section{Introduction}

We explore the dynamics of corporate risk management through which firms could create value by considering the following questions: How far ahead do firms hedge? What are the determinants of the maturity structure of firms’ hedging programs? What are the motivations for the early termination of hedging contracts? What are the real effects of hedging maturities on firm value? These questions related to the dynamics of corporate hedging are largely unexplored because of the lack of empirical analysis due to limitations of appropriate data. Using an extensive and new hand-collected dataset on the risk management activities of 150 US oil producers with quarterly observations over the period 1998-2010, we fill this gap in the literature and answer the above questions. It is important to understand why firms within the same industry and with the same oil price risk exposure differ in terms of their hedging maturity structure.

We contribute to the literature on corporate hedging in several ways. Previous studies, with the exception of Fehle and Tsyplakov (2005), discuss the maturity structure of hedging but do not investigate its determinants. ${ }^{1}$ Our first contribution is to provide empirical evidence of the determinants of the maturity structure of hedging contracts. We are also the first researchers to empirically study the rationales for the early termination of outstanding hedging contracts. We then apply the essential

\footnotetext{
${ }^{1}$ Dolde (1993) surveys the hedging practices of 244 Fortune 500 companies and finds that the common practice is to hedge cash flow exposures within a horizon of two to four quarters. In line with Dolde (1993), Tufano (1996) provides statistics about the percentage of the production hedged for North American gold mining firms for 1991-1993, and finds that they hedge 61.2\% of their gold production for the current year (1991) and 10\% and 11\% for the subsequent two years. In a Wharton survey of the financial risk management practices and derivatives of 399 US nonfinancial firms, Bodnar, Hayt, and Marston (1998) report that 82\% of the questioned firms use foreign currency derivatives with an initial maturity of 91 days or less and only $12 \%$ use foreign currency derivatives with maturities exceeding three years. They also find that hedging ratios at longer maturities decreased dramatically during 1998. Adam and Fernando (2006, 2008) study the cash flow gains from selective hedging for a sample of 92 North American gold producers from 1989 to 1999 and report the descriptive statistics of hedging ratios up to five years. They find that gold producers use hedging programs with one-year maturities in $90 \%$ of firm-quarters with nonzero hedging with a mean hedging ratio of $54 \%$ of the expected gold production, hedging programs with three-year maturities in $51 \%$ of hedging quarters with an average hedging ratio of $25 \%$, and programs with five-year maturities in $18 \%$ of hedging quarters with an average hedging ratio of $28 \%$. The authors also affirm that near-term hedging ratios are more volatile than those with longer horizons. Carter, Rogers, and Simkins (2006) investigate the jet fuel hedging activities of US airline firms during 1992-2003 and find that hedging maturities vary significantly between firms (e.g., from one year to six years ahead) and that the hedging ratios of the next year's fuel consumption are very disparate (e.g., from $1 \%$ to $43 \%$ ).
} 
heterogeneity model of Heckman, Urzua, and Vytlacil (2006) to evaluate the causal effects of hedging maturity structure on oil producers’ values. The essential heterogeneity model lets us differentiate either short- or long-term maturities effects on marginal firm value. To our knowledge, our study is among the first empirical works in the corporate finance literature that uses this methodology. Our data, collected from publicly disclosed information, provide detailed information about hedging activities. This detailed information allows us to study maturity structure by hedging instrument, namely, swap contracts, put options, and costless collars, which provides deeper insight into the hedging behavior of oil producers.

Some of our findings corroborate the predictions and results drawn from the theoretical model developed by Fehle and Tsyplakov (2005) based on simulations of the gold price paths and calibrated for firms in the gold mining industry. In their model, risk management contracts are modeled as a portfolio of forward contracts on the firm’s product price. They further estimate some relationships with real data. In line with their prediction and empirical results in the gold mining industry, we obtain strong evidence of a non-monotonic (concave) relationship between the hedging maturity and likelihood of financial distress measured by the leverage ratio. This non-monotonic relation means that hedging maturities increase and then decrease with the likelihood of financial distress and this is more evident for swap contracts. Results further show that the higher the distress costs, the longer the maturity of put options. There are at least two plausible explanations for this situation. First, distressed oil producers (i.e., those with insufficient cash inflows and higher leverage ratios) do this as a risk-shifting strategy. Costly put options with long maturities decrease assets available for debtholders. Second, distressed oil producers are undesirable hedging counterparties because of their high credit risk, thus put options are the only derivatives they can access for which their counterparties face no credit risk. 
In line with the theoretical contribution of Fehle and Tsyplakov (2005), we observe strong evidence of the impact of oil spot prices on the oil hedging maturity structure. In particular, the maturities of swaps contracts and costless collars increase and then decrease with oil spot prices. Results further show that larger oil producers tend to use put options with longer maturity, suggesting the presence of economies of scale in the hedging behavior of oil producers. There is also evidence of maturity matching between the expected life of oil reserves and the maturity of put options. Additional results show that hedging contract features (i.e., moneyness indicator and oil spot price at initiation of the hedging contract) have a significant impact on hedging maturity dynamics. Oil producers keep in-the-money hedging contracts until they mature. The results further imply that a hedging contract initiated when oil spot prices are sufficiently high is more likely to be kept for longer periods. Control variables related to gas production and hedging appear to have significant impacts on oil hedging maturity structure. Particularly, the gas hedging ratio for expected gas production is positively and significantly related to oil hedging maturity. Interestingly, the hedges of oil and gas market risks seem to be complementary.

We provide the first direct evidence of the motivations for the early termination of hedging contracts and find that the likelihood of financial distress has a convex relationship with the early termination of swap contracts in particular, indicating that oil producers with significantly higher leverage ratios terminate their swap positions prematurely. Moreover, oil spot prices have a convex relation with the early termination of costless collars, indicating that costless collars are terminated prematurely when oil prices are significantly high. This is probably done to stop losses due to the selling of a covered call option to form the costless collar. Larger oil producers, with longer debt maturity and longer expected oil reserve life, are reluctant to terminate their put options early.

To gain insight into the causal effects of the hedging maturity on firm value, we estimate the marginal treatment effects (MTEs) of using short-term versus long-term hedging contracts. We identify 
a credible instrument arising from the economic literature studying the macroeconomic responses to crude oil price shocks, namely the Kilian (2009) index which gives a measure of the demand for industrial commodities driven by economic perspectives. In our application an MTE is the value effect on the marginal firm entering long-term oil hedging contracts (treatment). After controlling for unobserved heterogeneity using the instrumental model of Heckman, Urzua, and Vytlacil (2006, 2006b), we show that the marginal firm value related to the use of long-term hedging contracts is lower than that related to the use of shorter contracts. This newly developed methodology allows us to better gauge the effects of hedging maturity choice on oil producers' values because it controls for bias arising from selection on unobservables (i.e., omitted variables) and selection on gain into treatment (i.e., selfselection) due to firms’ hidden background attributes.

The rest of the paper is organized as follows. Section 2 states our hypotheses. Section 3 describes our data and variables. Section 4 reports univariate results and Section 5 investigates the empirical evidence of the maturity structure of corporate risk management. Section 6 studies the early termination of hedging contracts. Section 7 examines the real implication of hedging maturity on firm value and Section 8 concludes the paper.

\section{Hypotheses}

The lack of testable theoretical predictions of hedging maturity structure is compensated for by Fehle and Tsyplakov (2005), who present an infinite-horizon continuous time model of a firm that can dynamically adjust the hedge ratio and maturity of its hedging instruments in response to fluctuations in firm output price. Their model is calibrated to replicate empirical observations for a gold mining firm and produces a number of new theoretical predictions pertaining to the optimal timing, adjustment, and rollover of hedging contracts and their maturities, which we will describe in depth to develop our 
hypotheses in this section and test empirically later. It is worth mentioning that Fehle and Tsyplakov's model is based on forward contracts but these contracts are not often used during our period of analysis. We will however test empirically their theoretical predictions for hedging instruments with linear payoffs (i.e., swap contracts) and other hedging tools with nonlinear payoffs (i.e., put options and costless collars).

\subsection{Financial distress}

A large body of the empirical literature has analyzed the positive relationship between financial constraints and firms’ hedging activities (e.g., Nance, Smith, and Smithson, 1993; Géczy, Minton, and Schrand, 1997; Tufano, 1996; Gay and Nam, 1998; Adam, 2002, 2009). In line with this literature, Fehle and Tsyplakov (2005) analyze the implications of financial distress on risk management adjustments. Based on simulations of gold spot prices, they find, in the presence of transaction costs, a non-monotonic relationship between hedging maturity and measures of financial distress probability. This nonmonotonicity means that hedging maturity first increases and then decreases with the probability of financial distress. Thus, firms near distress are often observed with short-run hedging contracts and could terminate longer contracts at a high cost due to risk-shifting behavior. Firms far from distress do not hedge or opt for short-term contracts because of the low marginal benefits of hedging (e.g., Stulz, 1996).

Fehle and Tsyplakov (2005) also find, theoretically, that financial distress costs are negatively related to hedging maturity. Distress costs increase when the firm's cash inflows are insufficient to cover production costs and debt payments. Their simulations show that firms with high distress costs tend to use shorter maturity hedging. Hence we posit the following empirical hypothesis: 
Hypothesis 1: Hedging maturity is negatively related to i) either the high or low likelihood of financial distress, and ii) higher distress costs.

Fehle and Tsyplakov (2005) also tested part (i) of the above hypothesis empirically with data from the gold mining industry. To further verify the empirical relevance of this prediction, we use the leverage ratio as measured by the book value of liabilities scaled by the book value of total assets. We add leverage squared to capture nonlinearity between financial soundness and hedging maturity. We predict a positive sign for the leverage ratio and a negative sign for its squared values.

We measure a firm's incurred distress costs by the product $I$ [ Leverage $-L]$ Max $[0,-p+c+$ d], where $I$ is an indicator function, Leverage is the leverage ratio, and $L$ is the median leverage ratio of our oil producers' sample, with $I[$ Leverage $-L]=1$ if Leverage $>L$ and zero otherwise. $\operatorname{Max}[0,-p+c+d]$ indicates that a firm incurs distress costs that are proportional to the shortfall of its realized selling prices $p$ compared with its production costs, represented by cash costs $c$ and debt payments $d$. These realized prices include the monetary effects of hedging activities, if any. Debt payments $d$ are measured by quarterly interest expenses and the outstanding proportion of long-term debt in current liabilities at the end of the quarter. The variables $p, c$, and $d$ are expressed per barrel of oil equivalent (BOE). Therefore, a firm incurs distress costs when its leverage is above the industry’s median and its actual cash inflows (i.e., realized selling prices net of production costs) are insufficient to meet debt requirements. These distress costs could entail higher future external financing costs.

\subsection{Market conditions}

The corporate hedging literature shows that market conditions, namely, spot prices and their volatilities, play a crucial role in why firms hedge, how much they hedge, and how they hedge (e.g., Bodnar, Hayt, and Marston, 1998; Brown and Toft, 2002; Adam, 2009). Fehle and Tsyplakov (2005) 
investigate the evolution of risk management contracts and spot price history by simulating the stochastic process of gold spot prices. They find strong evidence of a non-monotonic relationship between spot prices and hedging contract maturity. This result means that when spot prices are very high or very low, firms choose short maturity hedging. For the range of spot prices between these two extremes, firms tend to adjust their risk management instruments more frequently and then tend to enter into newly initiated contracts with longer maturities. Moreover, Fehle and Tsyplakov (2005) find that firms with higher price volatility tend to choose longer hedging contracts. In a higher price uncertainty environment, firms tend to refrain from costly early termination of their outstanding contracts unless spot prices increase significantly. These firms, in a higher-volatility environment, often conclude long-run contracts. We therefore posit the following hypothesis, which has not yet been tested with real data:

Hypothesis 2: Hedging maturity is negatively related to either very high or very low spot prices. Moreover, firms prefer longer-maturity contracts when product price volatility is higher.

We extract the oil spot prices observed at the end of each quarter from the Bloomberg Financial Markets Information database. ${ }^{2}$ We calculate the volatility of oil for each quarter as the standard deviation of daily spot prices within the quarter. We expect a positive sign for spot prices and volatilities and a negative sign for spot prices squared.

\subsection{Hedging contract features}

Fehle and Tsyplakov (2005) find that moneyness, remaining maturity, and spot prices at initiation of existing hedging contracts play an important role in optimal rollover and adjustment decisions. Regarding these features, they derive the following prediction, which we are the first to investigate empirically.

\footnotetext{
${ }^{2}$ We use the West Texas Intermediate (WTI) crude oil index as a proxy for oil spot prices.
} 
Hypothesis 3: Hedging contracts initiated when oil spot prices are higher are more likely to be kept until maturity because they are more likely to be in the money for a longer period.

We use the mean of oil spot prices during the quarter of the initiation of the hedging contract. To capture initiation dates, we skim the time series of the weighted-average maturity and detect initiation dates by choosing observations where maturity at time $t$ is superior to that at time $t-1$. Until another initiation date, we include a moneyness indicator that takes the value of 1 when the spot price at initiation of the outstanding hedging contract is greater than or equal to the average oil spot price during the current quarter and -1 otherwise. ${ }^{3}$ We predict a positive sign for both the spot price at initiation and the moneyness indicator on hedging maturity. More precisely, we use the following three definitions of moneyness indicator for each hedging contract type.

For swap contracts, the moneyness indicator takes the value of 1 if the oil spot price at the inception of the swap contract is greater than or equal to the average oil spot price during the current quarter. Otherwise, it takes the value of -1 . The oil spot price at the initiation represents the fixed-leg component specified by the swap contract, namely the swap price. We suppose that the company receives the fixed price and agrees to pay the floating-leg component of the swap tied to the WTI index.

For an oil producer, a hedge by costless collar includes buying a put option and selling a call option on crude oil, which creates a floor and a ceiling. For simplicity, we suppose that both options are initiated at the same strike price represented by the oil spot price at initiation of the collar. The moneyness indicator for a collar contract takes the value of 1 if the oil spot price at the inception of the collar contract is greater than or equal to the average oil spot price during the current quarter. Otherwise, it takes the

\footnotetext{
${ }^{3}$ An anonymous referee suggested that moneyness is the difference between contract guaranteed price and the spot price when the contract is forward. Therefore, for a forward contract, the contract guaranteed price should be the forward price. On the other hand, for a commodity swap, the price should be the price which equates the values between the fixed contract and a stream of discounted forward prices. For an option, it should be the strike price. For a costless collar, there should be two prices which are the floor and the cap. Unfortunately, we do not have the data permitting to use these definitions. We tank a referee for introducing them to us.
} 
value of -1 . When the oil spot price at the initiation of the collar is greater than the oil spot price during the current quarter, the oil producer incurs a hedging gain due to the exercise of its put option. Conversely, there will be hedging losses when the current oil spot price is greater than the guaranteed oil price by the collar due to the sold call option.

For put options, the moneyness indicator takes the value of 1 if the oil spot price at the inception of the put option is greater than or equal to the average spot price during the current quarter. Otherwise, it takes the value of -1 .

\subsection{Control variables}

\subsubsection{Production uncertainty}

Several studies, ${ }^{4}$ mostly theoretical, investigate the role of production activity characteristics on firms’ hedging behavior. These studies demonstrate the importance of production uncertainty (i.e., quantity risk) in firms' hedging programs. By deriving the optimal hedge analytically, Brown and Toft (2002) show that firms tend to hedge less for longer exposures because of the difficulty in accurately forecasting their future production. Consequently, production uncertainty should accentuate the inability to make accurate forecasts for future production. We explore the effects of production uncertainty and expect hedging maturity to be negatively related to production uncertainty. For each firm, we measure production uncertainty by the coefficient of the variation of daily production of oil with rolling windows of 12 quarterly observations available until the current quarter.

\footnotetext{
${ }^{4}$ These studies include those of Moschini and Lapan (1995), Brown and Toft (2002), Gay, Nam, and Turac (2002, 2003), and Adam (2009).
} 


\subsubsection{Maturity matching}

Maturity matching is a common best practice in corporate finance. We estimate the effect of the following two measures: 1) the weighted average maturity of debt, and 2) the expected life duration (in years) of developed oil reserves. The average debt maturity is calculated as the book value-weighted average maturities of debt that mature within one to five years. The expected life of reserves is calculated by dividing the current quantity of developed oil reserves by current annual oil production. These two variables allow us to capture any maturity matching between the firm's hedging positions and its major assets and future debt commitments.

\subsubsection{Gas production and hedging}

Natural gas production is an important part of our sample firms’ operations. We include control variables related to gas production and hedging to avoid overlocking this important aspect and to capture any effect on oil hedging behavior among the sample firms. ${ }^{5}$ We control for the quantity of proved gas reserves and gas production uncertainty. We further include the average hedging ratio for the expected future gas production over the subsequent five fiscal years. Gas spot prices and volatilities are also included.

Table 1 summarizes the definitions, construction, and data sources of the variables.

[Table 1 here]

\footnotetext{
${ }^{5}$ We thank an anonymous referee for this suggestion.
} 


\section{Sample construction and characteristics}

\subsection{Sample construction}

Our study is implemented on a sample of 150 US oil producers over the period 1998-2010. The oil industry is an excellent laboratory to test corporate risk management motivations and implications for several reasons. First, firms in this industry share homogeneous risk exposures (i.e., fluctuations in crude oil prices). Hence, diversity in hedging strategies is not due to differences in oil price risk exposure and is more likely to result from differences in firm characteristics such as oil and gas reserves, production risk and financial constraints. Second, financial derivatives on crude oil offer these firms several price hedging methods. Third, improvements in accounting disclosure related to petroleum producing activities have made operational data available. These data pertain to exploration, production and reserve quantities, cash costs, and so forth.

A preliminary list of 413 US oil producers with the primary Standard Industrial Classification (SIC) code $1311^{6}$ (crude petroleum and natural gas) was extracted from Bloomberg. Only firms that met the following criteria were retained: They have at least five years of oil reserve data during the period 1998-2010, their 10-K and 10-Q reports are available from the EDGAR website, and the firm is covered by Compustat. The filtering process produced a final sample of 150 firms with an unbalanced panel of 6,326 firm-quarter observations. To our knowledge, this sample is the most recent and the largest in the empirical literature on risk management in the petroleum industry.

Data on these firms' financial and operational characteristics were gathered from several sources. Data regarding financial characteristics were taken from the Compustat quarterly dataset held

\footnotetext{
${ }^{6}$ The SIC code 1311, crude petroleum and natural gas, comprises companies primarily involved in the operation of properties for the recovery of hydrocarbon liquids and natural gas.
} 
by Wharton Research Data Services (WRDS). Other items related to institutional shareholding were taken from the Thomson Reuters dataset maintained by WRDS. Data related to oil and gas reserves, production quantities, cash costs, and realized selling prices were taken from Bloomberg's annual data set and verified and supplemented by data hand-collected directly from 10-K annual reports. Quarterly data about oil producers' hedging activities were hand-collected from 10-K and 10-Q reports.

\section{2. $\quad$ Sample characteristics}

\subsubsection{Descriptive statistics: Dependent variable}

Our dependent variable is hedging maturity measured by the average remaining maturity weighted by the hedged notional quantity, as follows:

$$
H M_{i, j, t}=\sum_{T=g}^{g+5} \frac{N_{j, T} \times T}{\sum_{T=g}^{g+5} N_{j, T}}
$$

where $H M_{i, j, t}$ is the weighted-average remaining maturity for firm $i$ at quarter $t$ and hedging instrument $j$. The hedging instrument could be swap contracts, put options, costless collars, forward or futures contracts, and three-way collars; $N_{j, T}$ is the hedged notional quantity ${ }^{7}$ for instrument $j$ and horizon $T$; and $T$ ranges from the current fiscal year to five years ahead. We retain a maximum of five years ahead because we rarely find firms with hedging positions exceeding this horizon. The term $g$ takes the value of one at the beginning of the current fiscal year or a fraction of the year otherwise (e.g., 0.75 for nine months). We then have a maximum of six years covered when $g$ takes the value of one at the beginning of the current year.

\footnotetext{
${ }^{7}$ We follow Haushalter (2000) and use notional quantities for put options because we lack detailed information to calculate a delta percentage for these options. At least three attributes of our sample could mitigate this shortcoming in our study: i) Put options are used, on average, in $12 \%$ of firm-quarters with oil hedging; ii) put options are used most with either swaps or collars; and iii) the fraction of the quantity hedged by put options does not exceed $50 \%$.
} 
The weighted-average hedging maturity is a more refined measure of the hedging activities of nonfinancial firms. It simultaneously combines both sides of hedging programs, namely hedging extents and hedging horizons. It then appears to capture the motivations and real implications of the hedging activities of nonfinancial firms more efficiently.

Table 2 contains descriptive statistics of the weighted-average hedging maturity by hedging instruments. Overall, Table 2 shows average maturities (in years) of 1.227, 1.221, 1.083, 0.818, and 1.448 for swap contracts, costless collars, put options, forward/futures contracts, and three-way collars, respectively. It seems that oil hedgers adopt different hedging horizons for each hedging instrument. We also calculate the weighted-average maturity for the entire oil hedging portfolio, which could include two or more instruments used simultaneously. In this case, the weighted-average maturity for each instrument is weighted by its hedging ratio. The oil hedging portfolio has an average remaining maturity of 1.204. The statistics in Table 2 are in line with previous empirical findings that firms tend to hedge near-term positions.

[Table 2 here]

Table 2 also shows that oil hedging occurred in 2,607 firm-quarters (41.21\% of the firm-quarters in the sample) and presents a breakdown of the frequency of use for each hedging instrument. The most common hedging vehicles are swap contracts, with $45.25 \%$ of use (i.e., 1,711 firm-quarters out of 3,781 instrument-quarters of oil hedging). The second most frequently used instrument is costless collars, with $37.11 \%$ out of all instrument-quarters of oil hedging. Next are put options, with $11.85 \%$ of use. The least used instruments are forward or futures contracts, with only $2.78 \%$, and three-way collars, with only $3.02 \%$ of use. 


\subsubsection{Descriptive statistics: Independent variables}

Descriptive statistics are computed for the pooled dataset. Table 3 gives the mean, median, first quartile, third quartile, and standard deviations for the 150 US oil producers in the sample. Statistics show that oil producers have leverage ratios with a mean and median of about 52\%, which indicates little asymmetry in the distribution of the financial solvency of the sample firms. The statistics also indicate that oil producers incurred, on average, distress costs of \$3 per barrel. However, there are only 306 firm-quarters with positive financial distress costs (i.e., with a leverage ratio above the median and where the realized selling prices of oil are insufficient to cover production costs and debt requirements). For these observations, the average incurred distress cost incurred is about $\$ 57$ per barrel. The statistics further show relatively moderate oil production uncertainty, as measured by the coefficient of variation in daily production, with a mean (median) of $0.27(0.17)$ and one-fourth of the coefficients of variation exceeding 0.34 . This finding implies that oil producers have relatively stable production quantities. Debt maturity has a mean and median of two years. We see that developed oil reserves have expected life durations with a mean (median) of nine (7.5) years. Firm size has a mean (median) of about \$10 billion (\$481 million), indicating that our sample is constituted by a majority of small oil producers and a few larger ones. The summary statistics also indicate that our sample firms are not intensive gas hedgers. Half of the sample firms have nonzero gas hedging ratios with an average hedging ratio around $4 \%$ of the expected future gas production during the subsequent five fiscal years, albeit with substantial variation. We see high asymmetry in the distribution of gas reserves. As for oil production, the average gas production uncertainty could be considered moderate.

[Table 3 here] 


\section{Univariate results}

Table 4 presents univariate results comparing oil producers' characteristics and oil market conditions based on the remaining maturities of the outstanding hedging portfolios. We then classify the remaining weighted-average maturities as (1) short-term maturities (i.e., below the $33^{\text {rd }}$ percentile, which corresponds to one year ahead), (2) medium-term maturities if they fall between the $33^{\text {rd }}$ and $67^{\text {th }}$ percentiles (i.e., between one and 1.33 years ahead), and (3) long-term maturities, which exceed the $67^{\text {th }}$ percentile (i.e., more than 1.33 years ahead). We conduct tests of the differences between the means and medians of relevant variables to contrast short- to long-term maturities, short- to medium-term maturities, and medium-to long-term maturities. We compare means by using a $t$-test assuming unequal variances; medians are compared with a nonparametric Wilcoxon rank-sum Z-test and two-sided pvalues.

[Table 4 here]

We base our interpretation on univariate tests between firm-quarters with short-and long-term hedging maturities to ease the presentation of our results. The univariate tests in Table 4 show considerable differences in firm characteristics and oil market conditions between firm-quarters with long-term hedging maturities and those with short-term hedging maturities. The results indicate that oil producers with higher leverage ratios tend to choose longer maturities. This first univariate result does not corroborate our first hypothesis related to the non-monotonic relationship between hedging maturity and firm's financial distress as proxied by the leverage ratio. The results further show no significant differences for distress costs. Contrary to our predictions, higher production uncertainty is more closely related to long-run hedging maturities contracts. The results also provide empirical evidence of maturity matching between either firms’ assets or liabilities and hedging positions. In fact, 
oil producers with a longer debt structure and a higher expected reserve life tend to use longer hedging horizons. The results pertaining to market conditions suggest that higher oil spot prices and volatilities are associated more with longer oil hedging positions. These univariate results do not test the nonmonotonicity relationship between oil spot price and hedging maturity of Hypothesis 2 which will be studied in the multivariate analysis. Concerning control variables related to gas production and hedging, univariate tests show that users of long-term oil hedging contracts hedge their expected future gas production to a larger extent and have higher gas production uncertainty. Gas reserves appear to have no discernable differences between the different oil hedging maturities. As indicated in the last two lines of Table 4, gas spot prices and volatilities are associated more with the use of long-term oil hedging contracts. Univariate tests contrasting short- to medium-term maturities and medium- to long-term maturities reveal the same patterns as does the comparison between short- and long-term maturities. Overall, the mean and median comparisons yield very similar results.

Table 5 presents our results, comparing moneyness indicators and oil spot prices at initiation of hedging instruments based on their remaining maturities. For conciseness, we concentrate our analysis on the three major hedging instruments used by oil producers: swap contracts, put options, and costless collars. $^{8}$ As before, for each of the three instruments, we classify the hedging maturity as short, medium, or long term, based on the $33^{\text {rd }}$ and $67^{\text {th }}$ percentiles. The tests contrast short- with long-term maturities, short- with medium-term maturities, and medium- with long-term maturities. In line with the predictions, the comparisons reveal that hedging contracts with the shortest maturities have the least moneyness indicator value. This finding should show that oil producers tend to terminate their hedging positions that become deeply out-of-the money early, despite the incurred termination costs. In addition,

\footnotetext{
${ }^{8}$ We skip the observations related to forward/futures contracts and three-way collars in the analysis because they do not contribute enough to oil hedging. See Table 2. We have only 105 observations on forward and futures contracts for 8 companies, and 114 observations on three-ways collars.
} 
the results indicate that hedging contracts initiated when oil spot prices are high are more likely to be maintained for longer periods.

[Table 5 here]

\section{Maturity structure of corporate risk management}

To investigate the determinants of hedging maturity choice by oil producers, we estimate fixed effects regressions where the weighted-average remaining maturity is regressed on variables that measure financial distress likelihood and costs, production uncertainty, oil market conditions (oil spot price and volatility), asset-liability management, and hedging contract features. Other control variables related to gas reserves, production uncertainty, hedging, spot prices and volatilities are included. To obtain more insights into the hedging dynamics of oil producers, we estimate the regressions reported in Table 6 for the entire oil hedging portfolio and for the following major hedging instruments: swap contracts, put options, and costless collars. ${ }^{9}$

In line with our first hypothesis, the results pertaining to financial distress provide strong evidence of a non-monotonic (concave) relationship between hedging horizons and the likelihood of financial distress, as measured by the leverage ratio, for either the entire oil hedging portfolio or swap contracts individually. In fact, we find that the leverage ratio and leverage squared have economically and statistically significant positive and negative coefficients, respectively. These findings mean that oil

\footnotetext{
${ }^{9}$ To control for the possibility of sample selection bias, our regressions are derived in the context of the two-step Heckman regression with selection. This procedure captures the sequential decisions of oil producers: first, a decision to hedge oil or not and, second, a decision about hedging maturity. In the first step, we model the oil hedging decision as a function of the following variables: firm size, taxes, distance to default as a measure of the likelihood of financial distress, liquidity, dividend payout, investment opportunities, institutional ownership, geographical diversification in oil production, and managerial shareholding. See Table 1 for more details in the construction of these variables. The results of the first step are reported in Table A.1. This first step leads to the estimation of the inverse Mills ratio for the second step. Apart from the dividend payout, we find that all other variables are statistically significant and with appropriate signs, consistent with the literature on the decision to hedge (Tufano, 1996; Géczy, Minton, and Schrand, 1997; Graham and Rogers, 2002; Dionne and Garand, 2003).
} 
hedging maturities should first increase and then decrease with the likelihood of financial distress. It appears that oil producers that are either far from financial distress or deeply financially distressed neither initiate new hedging contracts nor roll over their expiring contracts, particularly swap contracts; and are thus observed with shorter hedging positions.

Distressed oil producers tend to choose shorter maturities because they do not seek the maximum insulation of firm value from oil price fluctuations as a risk-shifting strategy. Conversely, oil producers far from financial distress do not seek maximum protection in terms of maturity because their marginal benefit from oil hedging cannot outweigh the incurred transaction costs. For costless collars, this concave relationship is statistically less evident with a negative coefficient for leverage squared, which is only significant at conventional level of $10 \%$. In contrast, put options do not exhibit any relationship with the leverage ratio. Interestingly, latter findings show that the non-monotonic relationship between hedging maturity and financial distress, as predicted by Fehle and Tsyplakov’s model based on forward contracts, is not confirmed for hedging tools with nonlinear payoffs, particularly put options.

Figure 1 illustrates this non-monotonic relationship for the whole oil hedging portfolio, swap contracts, and costless collars, and contrasts our findings with those of Fehle and Tsyplakov (2005) for their sample of gold mining firms. The comparison with the empirical findings of Fehle and Tsyplakov (2005) for the gold mining industry indicates a lower magnitude of the coefficients related to financial distress proxies. In addition, the coefficients of leverage squared are markedly lower than those of the leverage ratio itself. It seems that the non-monotonic relationship between financial distress and hedging maturities is more pronounced for the gold mining industry than for the petroleum industry. ${ }^{10} 11$

\footnotetext{
${ }^{10}$ Fehle and Tsyplakov (2005) theoretical model is based on forward contract, and does not consider options and other hedging tools with nonlinear payoffs. However, one of their empirical estimations (see Table 16, page 41 in their paper) was made with all derivatives (including nonlinear instruments) in the aggregate hedging portfolio without explicitly taking their non-linearity into account.

${ }^{11}$ The leverage ratio for the gold mining firms studied by Fehle and Tsyplakov (2005) has an average (median) of 18\% (17\%). This leverage ratio is lower than that observed in our sample. Adam (2009), who studies relatively the same sample as Fehle and Tsyplakov (2005),
} 
[Table 6 and Figure 1 here]

In addition, we find that distressed oil producers incurring a higher dollar loss per BOE tend to use put options with longer maturities. Jensen and Meckling’s (1976) risk-shifting theory is one possible explanation for these findings. By entering costly long-term put options, distressed oil producers increase their firms’ payoff volatility, decrease assets available for debtholders, and preserve any upside potential for shareholders. A second possible explanation is that distressed oil producers are likely to be undesirable hedging counterparties because of high credit risk. Buying options provides the only mechanism through which low-credit-quality firms can engage because this is the only derivative position in which their counterparties will not face credit risk.

Our results also provide strong evidence of a non-monotonic (concave) relationship between oil spot prices and hedging maturities for the entire hedging portfolio, swap contracts, and costless collars, as predicted in our second hypothesis. Oil spot prices and spot prices squared have highly significant positive and negative coefficients, respectively. Figure 2 illustrates this non-monotonic relationship for the whole oil hedging portfolio, swap contracts, and costless collars and shows that it is more pronounced for costless collars. Contrary to the prediction, oil price volatility is negatively related to hedging maturity for the entire hedging portfolio and not significant otherwise.

[Figure 2 here]

Hedging contract features appear to have an obvious impact on hedging maturity choice, as predicted by Hypothesis 3. The results in Table 6 indicate that swap contracts and costless collars are more likely to be kept for longer periods when oil spot prices at the initiation of these contracts are sufficiently high. One possible explanation is that in a high oil spot price environment, hedging contracts

asserts that the leverage levels in the gold mining industry are characteristically low. He considers this as a sign of financial constraint because most of the gold mining firms are not sufficiently creditworthy to attract significant amounts of debt. 
are more likely to be initiated at higher prices, and hence to be in the money for longer periods. The maturity of the entire oil hedging portfolio is also significantly positively related to oil spot prices at initiation, however, the relation for put options is negative and statistically insignificant. As predicted, the results also show that hedging contracts with higher moneyness indicator tend to have longer maturities, showing that oil producers keep in-the-money hedging contracts until they mature.

The results further indicate that oil production uncertainty and average debt maturity appear to have no discernable impact on maturity for either the entire oil hedging portfolio or each of the hedging instruments. The expected life of developed oil reserves has a statistically significant positive impact on hedging maturity through put options. This finding provides empirical evidence of maturity matching between oil producers’ major assets and hedging horizons by put options. This result suggests that oil producers with higher expected oil production tend to use longer put options to fix a floor selling prices in the future. We also find that larger oil producers, in terms of size, tend to use longer put options. This finding adds support to economies of scale in hedging maturity choices, indicating that larger firms are more likely to have sufficient financial resources to finance put options’ premiums.

Relative to the other control variables related to gas production and hedging, we find that the hedging ratio of future gas production, over the subsequent five fiscal years, has an economically and statistically significant positive impact on maturity for either the entire oil hedging portfolio or each of the hedging instruments. Interestingly, this finding indicates some symmetric effects between hedging of oil and gas market risks. Similar to oil spot price, gas spot prices have a significant positive effect on the maturity of the entire oil hedging portfolio, swap contracts and costless collars. Gas price volatility has mixed effects. Although it reduces the maturity of swaps, it is positively related to collars’ maturity. Gas reserves have no evident impact on the maturity structure of oil hedging. Gas production uncertainty appears to motivate the use of costless collars to hedge longer oil exposures. Remarkably, gas price 
volatility and gas production uncertainty risk have an evident effect on the maturity of oil hedging by costless collars. Conversely, oil volatility and production risk do not have a similar impact on collars' maturity. Given that the oil and gas spot prices have a correlation coefficient equal to 0.66 during our sample period (1998-2010), we can infer that oil and gas hedges are used complementarily.

To further gauge the relevance of our findings, we re-calculate hedging maturities by using the maximum hedging horizon without accounting for the notional quantities for each point in time for oil hedging activity. Table A.2 reports the results of these additional regressions and reveals fairly similar results to the previous ones, yet with greater economic and statistical significance. However, the negative impact of oil price volatility is also statistically significant for swaps and collars' maturities which denies the second statement of our Hypothesis 2.

\section{Early termination of hedging contracts}

In this section, we take a closer look at risk management dynamics by studying the determinants of the early termination of outstanding hedging contracts. Termination of a hedging contract is considered early termination when the outstanding hedging contract has a remaining weighted-average maturity greater than or equal to six months. For each instrument, we create a dummy variable that takes the value of one when we find observations of no hedging preceded by an outstanding hedging contract with remaining maturity equal to six months or more, and zero otherwise. We then run random effects logit regressions of these dummy variables on the firm covariates previously used and the moneyness indicator and remaining maturity of the terminated hedging contract. Table 7 reports the results.

[Table 7 here]

We find evidence of a convex relationship between the early termination of swap contracts and leverage ratios in particular. This finding means that the likelihood of early termination of swap 
contracts decreases and then increases with the probability of financial distress, as shown by the economically and statistically significant negative and positive coefficients for the leverage ratio and its squared value, respectively. The results further show a not surprising convex relationship between oil spot prices and the early termination of costless collars, indicating that when oil spot prices attain higher levels, outstanding collars are actively terminated prematurely. Recall that costless collars involve buying a protective put option (i.e., floor) and selling a covered call option (i.e., ceiling), the early termination of collars could stop losses due to the short call position. ${ }^{12}$ Moreover, the early termination of collars lets firms profit from rising oil prices either by having no outstanding hedging vehicles to be fully exposed to the increasing oil prices or by negotiating new collar contracts with higher guaranteed oil price.

The early termination of swap contracts exhibits a less evident convex relationship with a negative coefficient for oil spot price, which is only significant at the conventional level of $10 \%$. Results further show that when oil price volatility is high, oil producers tend to terminate their put options’ positions prematurely. Although this latter finding contradicts the prediction, one possible explanation is that oil producers close out their positions by selling put options via a sell-to-close transaction in the options market and realize some revenue due to the increase in the put options' value caused by high oil price volatility.

Results in Table 7 also show that in-the-money swap contracts are less likely to be prematurely terminated. The remaining weighted maturity seems to have no significant impact on early termination decisions. In alternative specifications reported in the appendix (Table A.3), we rerun regressions using the remaining maturity without weighting by hedged quantities, and find a significant negative impact

\footnotetext{
${ }^{12}$ For example, when oil prices reached unprecedented levels in 2008, many oil producers that had used costless collars faced heavy margin calls, which were difficult to meet.
} 
on early termination decisions of put options and costless collars, indicating that these hedging vehicles are less likely to be prematurely terminated when they have longer remaining maturity. A possible explanation is that oil producers refrain from terminating their longer option-like contracts prematurely because they hope for more favorable prices in the future and to avoid transactions costs and premium payments associated to newly options' contracts. In-the-money swap contracts are kept until they mature, as predicted.

Further, production uncertainty prevents the early termination of swap contracts in particular. It seems that during periods of economic uncertainty, oil producers refrain from the early termination of their swap contracts to stabilize their generated cash flows. We further find that debt maturity, oil reserve life, and firm size are significantly negatively related to the early termination of outstanding put options. The longer the debt maturity, the longer the hedging maturity by put options. The reason for the positive relationship between oil reserve life and the maturity of put options is that the firm has a longer perspective due to the number of oil reserves.

\section{Real implications of hedging maturity structure}

In this section, we extend the controversial literature that focuses on the relationship between corporate hedging and firm value. One strand of this empirical literature finds either no support for the firm value maximization theory or a value discount due to derivative usage (Guay and Kothari, 2003; Lookman, 2003; Jin and Jorion, 2006; Fauver and Naranjo, 2010; and Phan, Nguyen and Faff, 2014). In contrast, another strand of the literature shows that firms' derivative transactions translate into increases in shareholder value (Allayannis and Weston, 2001; Graham and Rogers, 2002; Adam and Fernando, 2006; Carter, Rogers, and Simkins, 2006; Bartram, Brown, and Conrad, 2011; Choi, Mao, 
and Upadhyay, 2013; Pérez-Gonzales and Yun, 2013; Mnasri, Dionne, and Gueyie, 2017). Aretz and Bartram (2010) review the empirical literature on corporate hedging and firm value.

We complement the empirical literature by going into further detail and investigating the real implications of the maturity structure of corporate risk management on firm value. Firm value is measured by Tobin's $q$ calculated by the ratio of the market value of equity plus the book value of debt plus the book value of preferred shares to the book value of total assets. Tobin's $q$ is expressed with a logarithmic transformation because its distribution is strongly right skewed.

Endogeneity due to any reverse causality between firm hedging behavior and other firm financial decisions is a crucial concern in such a study; it is identified as the major source of inconsistency in some of the previous findings. To control for this endogeneity, we study the effects of choosing shortterm versus long-term hedging maturities on firm value using an econometric methodology that controls for biases related to omitted variables and self-selection, namely, essential heterogeneity models.

\subsection{Instrumental variable}

We identify one candidate instrument coming from the economics literature. For the choice of our candidate instrument, we build on our previous results in Table 6 (Columns 1 and 2) showing a significant impact of oil market conditions (spot price and volatility) on the maturity structure of the aggregate oil hedging portfolio. Armed with this strong empirical evidence, we look for an instrument that can explain the fluctuations of the real price of oil and that cannot affect the value of an oil producer directly. A large body of economic literature affirms that one of the most important fundamentals deriving industrial commodity prices is demand pressures or shocks induced by real economic activity. We consequently chose as instrument the Kilian (2009) index, a measure of the component of global 
real economic activity that derives demand for industrial commodities. This new measure is based on dry cargo (grain, crude oil, coal, iron ore, etc.) single-voyage ocean freight rates that captures demand shifts in global industrial commodity markets. The Kilian index, constructed monthly, accounts for different fixed effects for different routes, commodities and ship sizes. It is also deflated with the US consumer price index and linearly detrended to remove the decrease in real term over time of the cost of shipping of dry cargoes. Kilian (2009) shows that aggregate shocks for industrial commodities cause long swings in the real prices of oil, which differ from the increases and decreases in the price of oil induced by the oil market-specific demand shocks, which are more transitory. For our purposes, we calculate the changes in the Kilian (2009) index for each fiscal quarter in the sample. Changes in the Kilian index are calculated by taking the level of the index at the end of the current fiscal quarter (i.e., at the end of the last month of the fiscal quarter) minus its level at the end of the previous fiscal quarter.

\subsection{Essential heterogeneity approach}

To obtain insight into the dynamics of oil hedging maturities and their related real implications, we introduce potential heterogeneity between firms in the marginal evaluation of hedging maturity on firm value. As before, we classify oil hedging maturities below the $33^{\text {rd }}$ percentile, which corresponds to one year, ahead as short-term maturities; and those exceeding the $67^{\text {th }}$ percentile, which corresponds to 1.33 years ahead, as long-term maturities. We then create a dummy variable that takes the value of one for long-term maturities and zero for short-term maturities. In doing so, we are able to distinguish either short- or long-term hedging maturities’ contributions to value enhancement for oil producers. To overcome the endogeneity problem outlined previously, we use the newly developed IV methodology that controls for bias related to omitted variables and self-selection in the estimation of the Marginal 
Treatment Effects ${ }^{13}$ (MTEs) of hedging maturity choice, namely, the essential heterogeneity model of Heckman, Urzua, and Vytlacil (2006). We describe the model in the online appendix.

In Table A.4, we estimate the choice equation by a probit model, leading to the estimation of the propensity score of using long-term hedging maturities. The dependent variable is a dummy variable that takes the value of one for long-term maturities and zero for short-term maturities, as defined previously. Regressors in the choice equation are our candidate instrument (the Kilian index) and a set of control variables. Firm-level controls include return on assets, investment opportunities, quantity of oil reserves, oil production uncertainty, leverage ratio, liquidity, a dividend payout dummy, geographical diversification in oil production, institutional ownership, gas hedging ratio, gas reserves, and gas production uncertainty. Control variables also include oil and gas spot prices and volatilities. We further control for the recent financial crisis, accompanied by markedly higher oil volatility, by including dummy variable for the years 2008 and 2009 respectively. Table 1 describes the construction of these control variables.

The results show that the Kilian index appears to be a strong predictor of hedging maturity choice, with an economically and statistically significant negative coefficient, suggesting that oil producers tend to use short-term hedging positions in periods of increasing aggregate demand for industrial commodities because crude oil prices are more likely to increase driven by a vigorous real economic activity.

\footnotetext{
${ }^{13}$ The estimated MTE shows how the increment in the marginal firm value by going from choice 0 (short-term maturities) to choice 1 (long-term maturities) varies with different quantiles of the unobserved component of the desire to use long-term hedging maturity.
} 
Table 8 reports the results of the estimation of the outcome equation with respect to firm value. The output in Table 8 gives the estimations for both the treated and untreated groups. ${ }^{14}$ The outcome equation also indicates the average treatment effect (ATE), which captures the expected average benefit associated with the inducement in the treatment (i.e., using long-term hedging maturities in our case) conditional on observable independent variables. The ATE coefficient is not statistically significant, meaning that observable factors do not influence firm value. Further, Table 8 shows that return on assets (ROA) is significantly related to Tobin's $q$ for users of short-term hedging contracts. Liquidity and dividend payout appear to positively influence the Tobin's $q$ ratio for users of long-term hedging contracts. Oil price volatility has a statistically significant negative impact on firm value, indicating that investors prefer higher exposure to oil price fluctuations and tend to penalize hedging efforts at the firm level. However, this negative effect is statistically similar for the two groups (the $p$-value of the $t$-test is 0.87). Importantly, oil spot price is significantly negatively related to firm value for oil producers using long-term hedging maturities. When oil price tend to be higher, investors tend to penalize oil producers with longer hedging positions that do not allow benefit from this upward potential. Hedging extent for future gas production seems to influence negatively the firm value for users of long-term hedging maturities. Gas spot price has a significant positive effect on firm value which is statistically the same for the two groups (the $p$-value of the $t$-test is 0.1019 ). Gas reserves are associated with lower Tobin's $q$ for users of long-term hedging contacts. Gas production uncertainty influences negatively (positively) the firm value for users of long (short)-term hedges. Importantly, the propensity of inducement in oil hedging, as measured by the inverse Mills ratio, seems to be negatively related to the firm value of both groups with statistically the similar effect (the $p$-value of the $t$-test is 0.9191 ).

\footnotetext{
${ }^{14}$ The treated group consists of users of long-term hedging positions. The untreated group consists of users of short-term hedging positions. We use the Stata routine MARGTE developed by Brave and Walstrum (2014) to estimate the model of essential heterogeneity. We use the parametric normal approximation of the MTE with bootstrapped standard errors corrected for within-firm clustering. We run 500 replications.
} 
[Table 8 here]

The differences between the firms can be greater when non-observable factors are considered. Applying the standard IV approach with the two groups would reveal the effect of these observable differences on firm value. Yet all firms are considered homogenous (with respect to unobserved factors) in deriving an average maturity effect (one coefficient) on firm value. ${ }^{15}$ With the marginal treatment effect (MTE) methodology we may find that the marginal effect differs between the firms that have to be categorized in either group by adding the possibility of self-selection explained by unobserved factors.

Figure 3 plots the estimated MTEs with 95\% confidence intervals, evaluated at the means of the independent (observable) characteristics of oil producers over different quantiles of the unobserved resistance to use long-term hedging positions, namely, $U_{D}$. The ATE is also plotted (dashed line) as a reference point. In addition, estimated MTEs with their respective standard errors are reported in Table A.5 for different evaluation quantile points of $U_{D}$, from 0.01 to 0.99 . Estimated MTEs in the upper percentile are positive and statistically significant. Figure 3 shows that estimated MTEs are increasing with different quantiles of $U_{D}$, reflecting that the marginal Tobin's $q$ is lowest for oil producers that are more likely to use long-term hedging maturities (i.e., lower values of the unobserved component $U_{D}$ ). Table A.5 shows that estimated MTEs range from $-51 \%$ for high propensities to use long-term hedging positions to $90 \%$ for high propensities to use short-term hedges. This finding indicates that marginal oil producer’s value increases with hedging short-term horizons. Overall, our results show that marginal firm value decreases with the propensity to use longer hedging horizons or equivalently, increases with the propensity of using short-term horizons.

\footnotetext{
${ }^{15}$ As mentioned above, this average effect is not significant in our data.
} 
[Figure 3 here]

Interestingly, the curvature of the depicted MTEs in Figure 3, with respect to different quantiles of the unobserved component of the decision process of using long-term hedging positions, exhibits substantial heterogeneity in marginal treatment effects. This provides evidence of selection into treatment or a self-selection bias, indicating that the causal effects of the hedging maturity structure on firm value also vary across oil producers due to unobserved factors.

\section{Concluding remarks}

A substantial body of the theoretical corporate risk management literature has increased our understanding of the motivations, virtues, and value implications of hedging. This literature derives its theoretical and empirical predictions based on the extent of hedging or participation in hedging activities. Due to the lack of data, the dynamics structure of corporate risk management has been discussed in a largely descriptive manner in the empirical literature. In this study, we go beyond the classical questions in the corporate hedging literature to investigate: How far ahead do firms hedge? What are the determinants of the maturity structure of hedging programs of nonfinancial firms? And what are the effects of hedging maturities on firm value?

Using an extensive and new hand-collected dataset on the risk management activities of 150 US oil producers, we provide strong evidence that hedging maturities for swap contracts increase and then decrease with the likelihood of financial distress, as determined by Fehle and Tsyplakov (2005). Distressed oil producers, incurring high distress costs, enter longer put options as a risk-shifting strategy or due to their high credit risk. Consistent with the prediction, our results show a non-monotonic (concave) relationship between oil spot prices and hedging maturities, particularly for swap contracts and costless collars. In addition, hedging contract features (i.e., moneyness indicator, oil spot price at 
initiation) have an obvious impact on hedging maturity structure. Swap contracts and costless collars initiated when oil spot prices are high are more likely to have longer maturities. Results further show that oil producers keep their in-the-money contracts until they mature.

We also find evidence of maturity matching between put options and the expected life of developed oil reserves. Firm size is positively related to put option maturity, indicating economies of scale in hedging maturity choice due to option premiums. Interestingly, the gas hedge ratio of expected gas production, over the subsequent five fiscal years, is positively related to the maturity of oil hedges. This seems to provide evidence of maturity matching between oil and gas hedges. Gas market conditions have a significant impact on oil hedging maturity. The higher the gas spot prices, the longer the maturity of swap contracts and costless collars. Gas volatility has mixed effects. Gas production uncertainty is positively related to costless collar maturity.

We also provide the first direct evidence of the motivations for early termination of hedging contracts, which appears to be influenced by the likelihood of financial distress, oil spot prices, oil production uncertainty, debt maturity and the expected life of developed oil reserves, along with the contract's moneyness indicator. However, the impact of these determinants depends on the nature of the hedging contract (swap, put option, collar).

Finally, we explore the real effects of hedging maturity on firm value. To obtain further insight into the dynamics of these real implications, we consider heterogeneity between firms in the evaluation of the impact of hedging maturity on firm value. We use a newly developed methodology that deals with both sources of selection bias, namely, selection on unobservable variables and selection on gain into treatment. Our results show that the marginal firm value gain of selecting different hedging maturities is essentially due to the use of short-term hedging positions. More importantly, our results show an evident selection on gain into treatment due to unobserved factors in the choice of hedging 
maturity design (long- versus short-term horizon). Selection on gain into treatment means that the causal effects of the hedging maturity structure on firm value vary across oil producers.

\section{Acknowledgements}

We would like to thank the participants at the Northern Finance Association 2016 Annual Meeting for valuable discussion and comments. We are particularly grateful to the Editor and two anonymous referees for their detailed comments and suggestions. All errors are our own. 


\section{References}

Adam, T., 2002. Risk management and the credit risk premium. Journal of Banking and Finance 26, 243-269.

Adam, T., 2009. Capital expenditures, financial constraints, and the use of options. Journal of Financial Economics 92, 238-251.

Adam, T., Fernando, C.S., 2006. Hedging, speculation, and shareholder value. Journal of Financial Economics 81, 283-309.

Adam, T., Fernando, C.S., 2008. Can companies use hedging programs to profit from the market? Evidence from gold producers. Journal of Applied Corporate Finance 20, 91-102.

Allayannis, G., Weston, J.P., 2001. The use of foreign currency derivatives and firm market value. Review of Financial Studies 14, 243-276.

Aretz, K., Bartram, S.M., 2010. Corporate hedging and shareholder value. Journal of Financial Research 33, 317371.

Bartram, S.M., Brown, G.W., Conrad, J., 2011. The effects of derivatives on firm risk and value. Journal of Financial and Quantitative Analysis 46, 967-999.

Bodnar, G.M., Hayt, G.S., Marston, R.C., 1998. 1998 Survey of financial risk management by US nonfinancial firms. Financial Management 27, 70-91.

Brave, S., Walstrum, T., 2014. Estimating marginal treatment effects using parametric and semiparametric methods. Stata Journal 14, 191-217.

Brown, G.W., Toft, K.B., 2002. How firms should hedge. Review of Financial Studies 15, 1283-1324.

Carter, D.A., Rogers, D., Simkins, B.J., 2006. Does hedging affect firm value? Evidence from the US airline industry. Financial Management 35, 53-87.

Choi, J.J., Mao, C.X., Upadhyay, A.D., 2013. Corporate risk management under information asymmetry. Journal of Business Finance and Accounting 40, 239-271.

Crosbie, P.J., Bohn, R.J., 2003. Modeling Default Risk. KMV, LLC, San Francisco, CA.

Dionne, G., Garand., M., 2003. Risk management determinants affecting firms' values in the gold mining industry: New empirical results. Economic Letters 79, 43-52.

Dolde, W., 1993. The trajectory of corporate financial risk management. Journal of Applied Corporate Finance 6, 33-41.

Fauver, L., Naranjo, A., 2010. Derivative usage and firm value: The influence of agency costs and monitoring problems. Journal of Corporate Finance 16, 719-735.

Fehle, F., Tsyplakov, S., 2005. Dynamic risk management: Theory and evidence. Journal of Financial Economics 78, 3-47.

Gay, G.D., Nam., J. 1998. The underinvestment problem and corporate derivatives use. Financial Management 27, 53-69.

Gay, G.D., Nam., J., Turac, M., 2002. How firms manage risk: The optimal mix of linear and nonlinear derivatives. Journal of Applied Corporate Finance 14, 82-93.

Gay, G.D., Nam, J. Turac, M., 2003. On the optimal mix of corporate hedging instruments: Linear versus nonlinear derivatives. Journal of Futures Markets 23, 217-239.

Géczy, C., Minton, B.A., Schrand, C., 1997. Why firms use currency derivatives. Journal of Finance 52, $132-154$.

Graham, J., Smith, C.W., 1999. Tax incentives to hedge. Journal of Finance 54, 2241-2262. 
Graham, J.R., Rogers, D.A., 2002. Do firms hedge in response to tax incentives? Journal of Finance 57, 815-839.

Guay, W.R., Kothari, S.P., 2003. How much do firms hedge with derivatives? Journal of Financial Economics 70, 423-461.

Haushalter, D., 2000. Financing policy, basis risk, and corporate hedging: Evidence from oil and gas producers. Journal of Finance 55, 107-152.

Heckman, J.J., Urzua, S., Vytlacil, E.J., 2006. Understanding instrumental variables in models with essential heterogeneity. Review of Economics and Statistics 88, 389-432.

Heckman, J.J., Urzua, S., Vytlacil, E.J., 2006 b. Estimation of treatment effects under essential heterogeneity, Working $\quad$ University of $\quad$ Chicago, 20 pages. http://jenni.uchicago.edu/underiv/documentation 200603 20.pdf

Jensen, M.C., Meckling, W.H., 1976. Theory of the firm: Managerial behavior, agency costs and ownership structure. Journal of Financial Economics 3, 305-360.

Jin, Y., Jorion, P., 2006. Firm value and hedging: Evidence from U.S. oil and gas producers.” Journal of Finance 61, 893-919.

Kilian, L., 2009. Not all oil price shocks are alike: Disentangling demand and supply shocks in the crude oil market. American Economic Review 99, 1053-1069.

Lookman, A., 2003. Does hedging increase firm value? Comparing premia for hedging "big” versus "small” risks.” Working Paper, Carnegie Mellon University.

Merton, R.C., 1974. On the pricing of corporate debt: The risk structure of interest rates. Journal of Finance 29, 449470.

Mincer, J., 1974. Schooling, experience, and earnings. Cambridge: National Bureau of Economic Research.

Mnasri, M., Dionne, G., Gueyie, J.P., 2017. The use of non-linear hedging strategies by US oil producers: Motivation and implications. Energy Economics 63, 348-364.

Moschini, G., Lapan, H. 1995. The hedging role of options and futures under joint price, basis, and production risk. International Economic Review 36, 1025-1049.

Nance, D.R., Smith, C.W., Smithson, C.W., 1993. On the determinants of corporate hedging. Journal of Finance 48, 267-284.

Pérez-Gonzalez, F., Yun, H., 2013. Risk management and firm value: Evidence from weather derivatives. Journal of Finance 68, 2143-2176.

Phan, D., Nguyen, H., Faff, R., 2014. Uncovering the asymmetric linkage between financial derivatives and firm value - The case of oil and gas exploration and production companies. Energy Economics 45, 340-352.

Stulz, R.M., 1996. Rethinking risk management. Journal of Applied Corporate Finance 9, 8-24.

Tufano, P., 1996. Who manages risk? An empirical examination of risk management practices in the gold mining industry”. Journal of Finance 51, 1097-1137. 
Table 1: Variables’ Definitions, Construction, and Sources

\begin{tabular}{|c|c|c|c|}
\hline Variable Definition & Variable Name & Construction & Source \\
\hline \multicolumn{4}{|c|}{ Panel A: Variables in the hedging maturity structure regressions to test our main hypotheses } \\
\hline Leverage ratio & Leverage & Book value of total debts scaled by the book value of total assets. & Compustat \\
\hline $\begin{array}{l}\text { Financial distress } \\
\text { costs }\end{array}$ & Distress Costs & $\begin{array}{l}\text { Measured by } I[\operatorname{Lev}-L] \operatorname{Max}[0,-p+c+d] \text {, where } L e v \text { is the leverage ratio, } \\
L \text { is the median leverage ratio of the oil producers in the sample, } p \text { is realized } \\
\text { selling price, } c \text { is production cost, and } d \text { is debt payments, including interest } \\
\text { payments and debt reimbursements, with } p, c \text { and } d \text { expressed per BOE. This } \\
\text { variable is } I[L e v-L]=1 \text { if } L e v>L \text { and zero otherwise. }\end{array}$ & $\begin{array}{l}\text { Manually } \\
\text { constructed }\end{array}$ \\
\hline Oil spot price & Oil Spot Price & $\begin{array}{l}\text { Oil spot price represented by the WTI index on the NYMEX at the end of the } \\
\text { current quarter. }\end{array}$ & Bloomberg \\
\hline Oil price volatility & Oil Volatility & $\begin{array}{l}\text { Historical volatility (standard deviation) using the daily spot prices during the } \\
\text { quarter. }\end{array}$ & $\begin{array}{l}\text { Manually } \\
\text { constructed }\end{array}$ \\
\hline Firm size & Firm Size & $\begin{array}{l}\text { Number of common shares outstanding } \times \text { end-of-quarter per share price }+ \text { book } \\
\text { value of assets }- \text { book value of equity. The raw value of this variable (in } \$ \\
\text { millions) is used in Table } 3 \text { (Summary Statistics). The logarithm transformation } \\
\text { of this variable is used elsewhere. }\end{array}$ & Compustat \\
\hline $\begin{array}{l}\text { Oil spot price at } \\
\text { the initiation of the } \\
\text { hedging contract }\end{array}$ & $\begin{array}{l}\text { Spot Price at } \\
\text { Initiation }\end{array}$ & $\begin{array}{l}\text { Measured by the average oil spot price during the quarter of the initiation of the } \\
\text { hedging contract. }\end{array}$ & $\begin{array}{l}\text { Manually } \\
\text { constructed }\end{array}$ \\
\hline $\begin{array}{l}\text { Contract } \\
\text { moneyness } \\
\text { indicator }\end{array}$ & $\begin{array}{l}\text { Moneyness } \\
\text { Indicator }\end{array}$ & $\begin{array}{l}\text { A dummy variable that takes the value of one if the oil spot price at the inception } \\
\text { of the hedging contract is greater than or equal to the average spot price during } \\
\text { the current quarter. Otherwise, it takes the value of }-1 \text {. }\end{array}$ & $\begin{array}{l}\text { Manually } \\
\text { constructed }\end{array}$ \\
\hline $\begin{array}{l}\text { Contract’s } \\
\text { remaining maturity }\end{array}$ & $\begin{array}{l}\text { Remaining } \\
\text { Maturity }\end{array}$ & $\begin{array}{l}\text { The remaining weighted-average maturity at the termination date of the hedging } \\
\text { contract (in years). }\end{array}$ & $\begin{array}{l}\text { Manually } \\
\text { constructed }\end{array}$ \\
\hline \multicolumn{4}{|c|}{ Panel B: Other control variables in the hedging maturity structure regressions to test our main hypotheses } \\
\hline $\begin{array}{l}\text { Oil production } \\
\text { uncertainty }\end{array}$ & $\begin{array}{l}\text { Oil Production } \\
\text { Risk }\end{array}$ & $\begin{array}{l}\text { Coefficient of variation of daily oil production. This coefficient is calculated for } \\
\text { each firm by using rolling windows of } 12 \text { quarterly observations. Daily oil } \\
\text { production is disclosed annually. We repeat the same observation for the same } \\
\text { fiscal year quarters. }\end{array}$ & $\begin{array}{l}\text { Manually } \\
\text { constructed } \\
\text { Bloomberg } \\
\text { and } 10-\mathrm{K} \\
\text { reports }\end{array}$ \\
\hline $\begin{array}{l}\text { Weighted-average } \\
\text { maturity of debt (in } \\
\text { years) }\end{array}$ & Debt Maturity & $\begin{array}{l}\text { Calculated as the book value-weighted average maturities of debt that mature } \\
\text { within one, two, three, four, and five years. }\end{array}$ & $\begin{array}{l}\text { Manually } \\
\text { constructed }\end{array}$ \\
\hline $\begin{array}{l}\text { Expected life of oil } \\
\text { reserves (in years) }\end{array}$ & $\begin{array}{l}\text { Oil Reserves } \\
\text { Life }\end{array}$ & $\begin{array}{l}\text { Calculated by dividing the current quantity of developed oil reserves by the } \\
\text { current annual oil production. }\end{array}$ & $\begin{array}{l}\text { Manually } \\
\text { constructed }\end{array}$ \\
\hline Gas spot price & Gas Spot Price & $\begin{array}{l}\text { Constructed as an average index established from principal locations' indices in } \\
\text { the United States (Gulf Coast, Henry Hub, etc.). }\end{array}$ & Bloomberg \\
\hline Gas price volatility & Gas Volatility & $\begin{array}{l}\text { Historical volatility (standard deviation) using the daily spot prices during the } \\
\text { quarter. }\end{array}$ & $\begin{array}{l}\text { Manually } \\
\text { constructed }\end{array}$ \\
\hline $\begin{array}{l}\text { Hedging ratio of } \\
\text { the expected future } \\
\text { gas production }\end{array}$ & Gas Hedge Ratio & $\begin{array}{l}\text { The average hedging ratio of the expected future gas production over the } \\
\text { subsequent five fiscal years. For each fiscal year, we measure the gas hedging } \\
\text { ratio by the Fraction of Production Hedged (FPH) calculated by dividing the } \\
\text { notional hedged gas quantity by the expected gas production. We then average } \\
\text { these five hedging ratios. }\end{array}$ & $\begin{array}{l}\text { Manually } \\
\text { constructed }\end{array}$ \\
\hline $\begin{array}{l}\text { Gas production } \\
\text { uncertainty }\end{array}$ & $\begin{array}{l}\text { Gas Production } \\
\text { Risk }\end{array}$ & $\begin{array}{l}\text { Coefficient of variation of daily gas production. This coefficient is calculated for } \\
\text { each firm by using rolling windows of } 12 \text { quarterly observations. Daily gas } \\
\text { production is disclosed annually. We repeat the same observation for the same } \\
\text { fiscal year quarters. }\end{array}$ & $\begin{array}{l}\text { Manually } \\
\text { constructed } \\
\text { Bloomberg } \\
\text { and } 10-K \\
\text { reports }\end{array}$ \\
\hline Gas reserves & Gas Reserves & $\begin{array}{l}\text { The quantity of the total proved developed and undeveloped gas reserves. This } \\
\text { variable is disclosed annually. We repeat the same observation for the same } \\
\text { fiscal year quarters. The raw value of this variable (in billions of cubic feet) is } \\
\text { used in Table } 3 \text { (Summary Statistics). The logarithm transformation of this } \\
\text { variable is used elsewhere. }\end{array}$ & $\begin{array}{l}\text { Bloomberg } \\
\text { and } 10-\mathrm{K} \\
\text { reports }\end{array}$ \\
\hline
\end{tabular}


Table 1 (continued)

\section{Panel C: Variables in the oil hedging decision regression}

Tax save

Distance to default $\quad$ DTD

Tax liability saving arising from a reduction of $5 \%$ of taxable income (Graham and Smith, 1999).

Market-based measure of default risk based on Merton's (1974) approach and used by Moody's KMV. The DTD is equal to $\frac{V_{a}-D}{V_{a} \sigma_{a}}$, where D is defined as long-term debt in current liabilities plus one-half of long-term debts, $V_{a}$ is the market value of assets, and $\sigma_{a}$ is one-year asset volatility. The quantities $V_{a}$ and $\sigma_{a}$ are unobservable and are approximated from Merton's (1974) model by using the market value and volatility of equity, the three-month Treasury bill rate, and debts (D). See Crosbie and Bohn (2003) for more details on the construction of the DTD.

Investment

opportunities

Liquidity

Dividend payout

Institutional

ownership

Geographical

diversification in

oil production

activities

Market value of shared owned by the CEO
Investment

Opportunities

Liquidity

Dvd Payout

Inst Ownership

Geo

Diversification

CEO Ownership

Following Haushalter (2000), we use the total costs incurred in property acquisition, exploration, and development, scaled by net property, plant, and equipment at the beginning of the quarter.

Book value of cash and cash equivalents divided by the book value of current liabilities.

Dummy variable for dividends declared during the quarter.

Percentage of firm shares held by institutional investors.

Equals $1-\sum_{i=1}^{N}\left(\frac{q_{i}}{q}\right)^{2}$, where $q_{i}$ is the daily oil production in region $i$ (Africa, Latin America, North America, Europe, and the Middle East) and $q$ is the firm's total daily oil production.

Measured by the logarithm of 1 plus the market value of common shares held by the CEO at the end of each quarter.
Manually constructed

Manually constructed
Bloomberg and $10-\mathrm{K}$ reports

Manually constructed

Manually constructed

Manually constructed

Manually constructed

Thomson Reuters

\section{Panel D: Variables in the firm value implications regression}

Firm value

Oil reserves

Return on assets

ROA

Financial crisis

2008 and 2009

Panel E: Instrumental variable

Changes in Kilian $\Delta$ Kilian Index

(2009) index
Calculated by the ratio of the market value of equity plus the book value of debt plus the book value of preferred shares divided by the book value of total assets.

The quantity (in millions of barrels) of the total proved developed and undeveloped oil reserves (in logarithm). This variable is disclosed annually. We repeat the same observation for the same fiscal year quarters.

Quarterly net income divided by the book value of total assets.

Dummy variable for each year 2008 and 2009.

Variations in the Kilian (2009) Index. This index is publicly available in a monthly frequency (http://www-personal.umich.edu/ lkilian). For each firm in the sample, we calculate changes in the Kilian index by taking the level of the index at the end of the current fiscal quarter (i.e., at the end of the last month in the fiscal quarter) minus its level at the end of the previous fiscal quarter.
Manually constructed

Bloomberg and $10-\mathrm{K}$ reports

Manually constructed

Manually constructed

Web site of the author Lutz Kilian

This table presents the definitions, construction, and data sources for the independent variables. 
Table 2: Weighted-average maturity by hedging instrument (in years)

\begin{tabular}{lccccccccc}
\hline Hedging instrument & Obs & \% of use & Mean & Median & $1^{\text {st }}$ Quartile & $3^{\text {rd }}$ Quartile & Min & Max & Std Dev \\
\hline Swap contracts & 1711 & $45.25 \%$ & 1.227 & 1.061 & 0.750 & 1.530 & 0.250 & 3.758 & 0.644 \\
Costless collars & 1403 & $37.11 \%$ & 1.221 & 1.050 & 0.799 & 1.500 & 0.250 & 4.439 & 0.621 \\
Put options & 448 & $11.85 \%$ & 1.083 & 1.000 & 0.750 & 1.416 & 0.250 & 2.970 & 0.548 \\
Forwards or futures & 105 & $2.78 \%$ & 0.818 & 0.750 & 0.500 & 1.000 & 0.250 & 1.750 & 0.332 \\
3-way collars & 114 & $3.02 \%$ & 1.448 & 1.230 & 0.855 & 1.840 & 0.250 & 4.212 & 0.878 \\
Oil hedging portfolio & 2607 & & 1.204 & 1.061 & 0.820 & 1.489 & 0.250 & 3.935 & 0.575
\end{tabular}

maturity(a)

This table presents summary statistics pertaining to the weighted-average maturity by hedging instrument and for the whole oil hedging portfolio. The observations are firm-quarters.

(a) The number of firm-quarters for the aggregate hedging portfolio should not be calculated as the sum of firm-quarters for each instrument. In fact, for a given firm-quarter, an oil producer can use more than one instrument simultaneously.

Table 3: Summary statistics

\begin{tabular}{|c|c|c|c|c|c|c|}
\hline Variables & Obs & Mean & Median & $1^{\text {st }}$ Quartile & $3^{\text {rd }}$ Quartile & Std.Dev \\
\hline Leverage & 6,044 & 0.516 & 0.523 & 0.342 & 0.658 & 0.285 \\
\hline Distress Costs (\$/BOE) & 5,732 & 3.056 & 0.000 & 0.000 & 0.000 & 34.167 \\
\hline Oil Production Risk & 6,246 & 0.272 & 0.168 & 0.079 & 0.344 & 0.302 \\
\hline Debt Maturity (in years) & 6,116 & 2.000 & 2.000 & 0.000 & 3.349 & 1.640 \\
\hline Oil Reserves Life (in years) & 6,157 & 9.055 & 7.542 & 5.050 & 10.639 & 10.846 \\
\hline Firm Size (in \$millions) & 5,920 & 9,782 & 481 & 91 & 2,901 & 44,542 \\
\hline Gas Hedge Ratio & 6,326 & 0.044 & 0.000 & 0.000 & 0.043 & 0.104 \\
\hline Gas Reserves (in Billions of cubic feet) & 6,326 & 1,504 & 99 & 14 & 572 & 5,888 \\
\hline Gas Production Risk & 6,222 & 0.272 & 0.181 & 0.092 & 0.360 & 0.281 \\
\hline Firm value (Tobin’s $q$ ) & 5,912 & 1.811 & 1.442 & 1.130 & 1.935 & 1.426 \\
\hline
\end{tabular}

This table provides quarterly summary statistics for the 150 US oil producers for the period 1998-2010. Variables are defined in Table I. The observations are firm-quarters.

Table 4: Characteristics of oil producers and market conditions by hedging maturity

\begin{tabular}{|c|c|c|c|c|c|c|c|c|c|c|c|c|c|c|c|}
\hline \multirow[b]{2}{*}{ Variables } & \multicolumn{3}{|c|}{ Short maturity } & \multicolumn{3}{|c|}{ Medium maturity } & \multicolumn{3}{|c|}{ Long maturity } & \multicolumn{2}{|c|}{ Short vs. Long } & \multicolumn{2}{|c|}{ Short vs. Medium } & \multicolumn{2}{|c|}{ Medium vs. Long } \\
\hline & Obs & Mean & Median & Obs & Mean & Median & Obs & Mean & Median & $t$-test & Z-score & $t$-test & Z-score & $t$-test & Z-score \\
\hline Leverage & 837 & 0.595 & 0.568 & 889 & 0.580 & 0.567 & 858 & 0.618 & 0.595 & $-2.089 * *$ & $-3.500 * * *$ & 1.338 & 0.578 & $-3.747 * * *$ & $-4.256 * * *$ \\
\hline Distress Costs & 814 & 0.689 & 0.000 & 857 & 1.166 & 0.000 & 828 & 1.113 & 0.000 & -1.197 & 0.555 & -1.187 & 0.433 & 0.115 & 0.134 \\
\hline Oil Production Risk & 846 & 0.219 & 0.154 & 894 & 0.220 & 0.154 & 867 & 0.269 & 0.171 & $-4.171^{* * *}$ & -0.977 & -0.078 & 0.372 & $-4.115^{* * *}$ & -1.271 \\
\hline Debt Maturity & 846 & 2.281 & 2.537 & 894 & 2.576 & 3.000 & 867 & 2.804 & 3.021 & $-6.665 * * *$ & $-6.738 * * *$ & $-3.737 * * *$ & $-4.024 * * *$ & $-2.937 * * *$ & $-2.775 * * *$ \\
\hline Oil Reserves Life & 846 & 7.779 & 6.927 & 894 & 8.119 & 7.426 & 867 & 9.634 & 8.892 & $-7.595 * * *$ & $-9.760 * * *$ & -1.633 & $-2.086 * *$ & $-6.268 * * *$ & $-7.545 * * *$ \\
\hline Firm Size (in log) & 828 & 7.179 & 6.985 & 879 & 7.455 & 7.416 & 852 & 7.702 & 7.687 & $-6.232 * * *$ & $-6.089 * * *$ & $-3.374 * * *$ & $-3.404 * * *$ & $-3.095 * * *$ & $-2.999 * * *$ \\
\hline Oil Spot price & 845 & 46.924 & 32.50 & 894 & 53.724 & 49.64 & 867 & 68.509 & 69.89 & $-16.799 * * *$ & $-16.702 * * *$ & $-5.013 * * *$ & $-5.402 * * *$ & $-11.488 * * *$ & $-11.554^{* * *}$ \\
\hline Oil Volatility & 845 & 3.092 & 2.371 & 894 & 3.672 & 2.738 & 867 & 4.617 & 3.548 & $-10.618^{* * *}$ & $-13.729 * * *$ & $-4.277^{* * *}$ & $-5.135 * * *$ & $-6.055^{* * *}$ & $-9.257 * * *$ \\
\hline Gas Hedge Ratio & 846 & 0.042 & 0.008 & 894 & 0.053 & 0.024 & 867 & 0.145 & 0.098 & $-15.818 * * *$ & $-17.439 * * *$ & $-3.154 * * *$ & $-4.293 * * *$ & $-14.000 * * *$ & $-14.619 * * *$ \\
\hline Gas Reserves (in log) & 841 & 5.703 & 5.755 & 889 & 5.792 & 5.763 & 861 & 5.836 & 5.765 & -1.474 & -1.517 & -0.989 & -0.965 & -0.501 & -0.551 \\
\hline Gas Production Risk & 846 & 0.209 & 0.155 & 894 & 0.217 & 0.162 & 867 & 0.293 & 0.185 & $-7.178 * * *$ & $-4.504 * * *$ & -0.912 & -0.253 & $-6.212 * * *$ & $-4.317 * * *$ \\
\hline Gas Spot Price & 845 & 4.885 & 4.740 & 894 & 5.454 & 5.280 & 867 & 6.149 & 5.790 & $-10.457 * * *$ & $-12.451 * * *$ & $-4.641^{* * *}$ & $-5.518 * * *$ & $-5.709 * * *$ & $-6.331 * * *$ \\
\hline Gas Volatility & 845 & 0.676 & 0.455 & 894 & 0.797 & 0.543 & 867 & 0.903 & 0.889 & $-8.729 * * *$ & $-10.775 * * *$ & $-4.571 * * *$ & $-5.681 * * *$ & $-4.182 * * *$ & $-5.535 * * *$ \\
\hline
\end{tabular}

This table provides the mean and median values of oil producer characteristics and market conditions according to the weightedaverage maturity of the oil hedging portfolio. For each firm-quarter with hedging activity, a hedging portfolio maturity is classified as short term if it is less than the $33^{\text {rd }}$ percentile of the weighted-average maturity (i.e., one year ahead), medium term if it is between the $33^{\text {rd }}$ and $67^{\text {th }}$ percentiles (i.e., between one and 1.33 years ahead), and long term if it exceeds the $67^{\text {th }}$ percentile (i.e., more than 1.33 years ahead). The variables are defined in Table 1. Comparison of means is constructed using a $t$-test assuming unequal variances; comparison of medians is constructed by using the nonparametric Wilcoxon rank sum Z-score. Two sided $p$-values are reported. The superscripts ***, ${ }^{* *}$, and * indicate statistical significance at the $1 \%, 5 \%$, and $10 \%$ levels, respectively. 
Table 5: Contract features by hedging maturity

\begin{tabular}{|c|c|c|c|c|c|c|c|c|c|c|c|c|c|c|c|}
\hline \multirow[b]{2}{*}{ Variables } & \multicolumn{3}{|c|}{ Short maturity } & \multicolumn{3}{|c|}{ Medium maturity } & \multicolumn{3}{|c|}{ Long maturity } & \multicolumn{2}{|c|}{ Short vs. Long } & \multicolumn{2}{|c|}{ Short vs. Medium } & \multicolumn{2}{|c|}{ Medium vs. Long } \\
\hline & Obs & Mean & Median & Obs & Mean & Median & Obs & Mean & Median & $t$-test & Z-score & $t$-test & Z-score & $t$-test & Z-score \\
\hline Swap contracts & & & & & & & & & & & & & & & \\
\hline Moneyness Indicator & 564 & -0.337 & -1.000 & 582 & 0.306 & 1.000 & 565 & 0.094 & 1.000 & $-7.461 * * *$ & $-7.286 * * *$ & $-11.479 * * *$ & $-10.873 * * *$ & $3.681 * * *$ & $3.664 * * *$ \\
\hline $\begin{array}{l}\text { Spot Price at Initiation } \\
\text { Put options }\end{array}$ & 564 & 41.237 & 31.155 & 582 & 47.976 & 43.182 & 565 & 62.502 & 60.048 & $-14.822 * * *$ & $-14.712 * * *$ & $-4.594 * * *$ & $-5.326 * * *$ & $-10.051 * * *$ & $-10.349 * * *$ \\
\hline Moneyness Indicator & 150 & -0.120 & -1.000 & 145 & 0.227 & 1.000 & 153 & 0.412 & 1.000 & $-4.838^{* * *}$ & $-4.672 * * *$ & $-3.025 * * *$ & $-2.983 * * *$ & $-1.678^{*}$ & $-1.676^{*}$ \\
\hline $\begin{array}{l}\text { Spot Price at Initiation } \\
\text { Costless collars }\end{array}$ & 148 & 49.435 & 38.314 & 145 & 52.470 & 48.305 & 152 & 66.316 & 64.952 & $-4.755^{* * *}$ & $-4.729 * * *$ & -0.929 & -1.484 & $-4.133^{* * *}$ & $-3.803^{* * *}$ \\
\hline Moneyness Indicator & 468 & -0.252 & -1.000 & 472 & 0.317 & 1.000 & 463 & 0.127 & 1.000 & $-5.903 * * *$ & $-5.799 * * *$ & $-9.110 * * *$ & $-8.737 * * *$ & $2.995^{* * *}$ & $2.984^{* * *}$ \\
\hline $\begin{array}{l}\text { Spot Price at Initiation } \\
\text { Forward contracts }\end{array}$ & 468 & 50.266 & 43.908 & 472 & 55.040 & 59.685 & 463 & 67.996 & 63.181 & $-10.129 * * *$ & $-10.359 * * *$ & $-2.814 * * *$ & $-3.777 * * *$ & $-7.860 * * *$ & $-6.559 * * *$ \\
\hline Moneyness Indicator & 29 & -0.379 & -1.000 & 34 & 0.000 & 0.000 & 42 & 0.523 & 1.000 & $-4.110^{* * *}$ & $-3.760 * * *$ & -1.537 & -1.512 & $-2.391 * *$ & $-2.356 * *$ \\
\hline Spot price at initiation & 29 & 40.971 & 31.155 & 34 & 38.786 & 30.685 & 42 & 59.487 & 43.908 & $-2.725^{* * *}$ & $-2.127 * *$ & 0.373 & 0.628 & $-3.055 * * *$ & $-2.821 * *$ \\
\hline
\end{tabular}

This table provides the mean and median values of the hedging instruments features (i.e., moneyness indicator and spot price at the initiation of the hedging contract) according to the weighted-average maturity. Hedging contracts are swap contracts, put options, costless collars, and forward contracts. Spot Price at Initiation is measured by the average oil spot price during the quarter of initiation of the hedging contract. The variable Moneyness Indicator is a dummy variable that takes the value of 1 when the spot price at initiation of the hedging contract is greater or equal to the average oil spot price during the current quarter, and -1 otherwise. For each instrument, hedging maturity is classified as short term if it is less than the $33^{\text {rd }}$ percentile of the weighted-average maturity, medium term if it is between the $33^{\text {rd }}$ and $67^{\text {th }}$ percentiles, and long term if it exceeds the $67^{\text {th }}$ percentile. Comparison of means is constructed using a $t$-test assuming unequal variances; comparison of medians is constructed by using the nonparametric Wilcoxon rank sum Z-score. Two sided $p$-values are reported. The superscripts ***, **, and * indicate statistical significance at the $1 \%, 5 \%$, and $10 \%$ levels, respectively. 
Table 6

Oil hedging maturity structure

\begin{tabular}{|c|c|c|c|c|c|c|c|c|}
\hline & $(1)$ & $(2)$ & (3) & (4) & (5) & (6) & $(7)$ & $(8)$ \\
\hline Variables & Oil Hedging & Oil Hedging & Swap Contracts & Swap Contracts & Put Options & Put Options & Costless Collars & Costless Collars \\
\hline Leverage & $\begin{array}{c}0.9724^{* * *} \\
(0.361)\end{array}$ & $\begin{array}{c}1.1751^{* * *} \\
(0.370)\end{array}$ & $\begin{array}{c}1.7418^{* * *} \\
(0.495)\end{array}$ & $\begin{array}{c}2.0104^{* * *} \\
(0.500)\end{array}$ & $\begin{array}{c}-0.4836 \\
(0.639)\end{array}$ & $\begin{array}{c}-0.1961 \\
(0.631)\end{array}$ & $\begin{array}{l}0.7803 \\
(0.702)\end{array}$ & $\begin{array}{c}0.8549 \\
(0.686)\end{array}$ \\
\hline Leverage Squared & $\begin{array}{c}-0.6388^{* *} \\
(0.244)\end{array}$ & $\begin{array}{c}-0.7369 * * * \\
(0.246)\end{array}$ & $\begin{array}{c}-1.2114 * * * \\
(0.310)\end{array}$ & $\begin{array}{c}-1.3268^{* * *} \\
(0.318)\end{array}$ & $\begin{array}{l}0.6601 \\
(0.427)\end{array}$ & $\begin{array}{l}0.4929 \\
(0.431)\end{array}$ & $\begin{array}{c}-0.5492 \\
(0.370)\end{array}$ & $\begin{array}{c}-0.5982 * \\
(0.359)\end{array}$ \\
\hline Distress Costs & $\begin{array}{l}0.0028 \\
(0.002)\end{array}$ & $\begin{array}{l}0.0027 \\
(0.002)\end{array}$ & $\begin{array}{l}0.0034 \\
(0.003)\end{array}$ & $\begin{array}{l}0.0033 \\
(0.003)\end{array}$ & $\begin{array}{c}0.0075^{* *} \\
(0.003)\end{array}$ & $\begin{array}{l}0.0047 \\
(0.003)\end{array}$ & $\begin{array}{l}0.0011 \\
(0.001)\end{array}$ & $\begin{array}{l}0.0005 \\
(0.001)\end{array}$ \\
\hline Oil Spot Price & & $\begin{array}{c}0.0214 * * * \\
(0.004)\end{array}$ & & $\begin{array}{c}0.0242 * * * \\
(0.006)\end{array}$ & & $\begin{array}{l}0.0017 \\
(0.005)\end{array}$ & & $\begin{array}{c}0.0147^{* * *} \\
(0.003)\end{array}$ \\
\hline Spot Squared & & $\begin{array}{c}-0.0001^{* * *} \\
(0.000)\end{array}$ & & $\begin{array}{c}-0.0001^{* * *} \\
(0.000)\end{array}$ & & $\begin{array}{r}-0.0000 \\
(0.000)\end{array}$ & & $\begin{array}{c}-0.0001^{* * *} \\
(0.000)\end{array}$ \\
\hline Oil Volatility & $\begin{array}{c}-0.0156^{* * *} \\
(0.004)\end{array}$ & & $\begin{array}{c}-0.0102 \\
(0.006)\end{array}$ & & $\begin{array}{r}-0.0030 \\
(0.008)\end{array}$ & & $\begin{array}{l}-0.0155 \\
(0.010)\end{array}$ & \\
\hline Spot Price at Initiation & $\begin{array}{c}0.0037 * * * \\
(0.001)\end{array}$ & & $\begin{array}{c}0.0061^{* * *} \\
(0.002)\end{array}$ & & $\begin{array}{r}-0.0010 \\
(0.002)\end{array}$ & & $\begin{array}{c}0.0038 * * \\
(0.002)\end{array}$ & \\
\hline Moneyness Indicator & & $\begin{array}{c}0.0847^{* * * *} \\
(0.009)\end{array}$ & & $\begin{array}{c}0.1181 * * * \\
(0.013)\end{array}$ & & $\begin{array}{c}0.1049 * * * \\
(0.026)\end{array}$ & & $\begin{array}{c}0.1179 * * * \\
(0.014)\end{array}$ \\
\hline Oil Production Risk & $\begin{array}{l}0.0527 \\
(0.089)\end{array}$ & $\begin{array}{l}0.1183 \\
(0.087)\end{array}$ & $\begin{array}{l}0.1961 \\
(0.181)\end{array}$ & $\begin{array}{l}0.2505 \\
(0.175)\end{array}$ & $\begin{array}{l}0.3557 \\
(0.237)\end{array}$ & $\begin{array}{l}0.3557 \\
(0.236)\end{array}$ & $\begin{array}{l}0.0496 \\
(0.148)\end{array}$ & $\begin{array}{l}0.0502 \\
(0.139)\end{array}$ \\
\hline Debt Maturity & $\begin{array}{l}0.0082 \\
(0.012)\end{array}$ & $\begin{array}{l}-0.0003 \\
(0.012)\end{array}$ & $\begin{array}{l}0.0083 \\
(0.016)\end{array}$ & $\begin{array}{c}-0.0033 \\
(0.015)\end{array}$ & $\begin{array}{l}0.0047 \\
(0.026)\end{array}$ & $\begin{array}{r}-0.0040 \\
(0.025)\end{array}$ & $\begin{array}{c}-0.0019 \\
(0.024)\end{array}$ & $\begin{array}{l}-0.0107 \\
(0.024)\end{array}$ \\
\hline Oil Reserves Life & $\begin{array}{l}0.0035 \\
(0.004)\end{array}$ & $\begin{array}{l}0.0034 \\
(0.004)\end{array}$ & $\begin{array}{l}0.0147 \\
(0.009)\end{array}$ & $\begin{array}{l}0.0124 \\
(0.008)\end{array}$ & $\begin{array}{c}0.0108^{*} \\
(0.006)\end{array}$ & $\begin{array}{c}0.0114^{* *} \\
(0.005)\end{array}$ & $\begin{array}{c}-0.0043 \\
(0.007)\end{array}$ & $\begin{array}{c}-0.0033 \\
(0.007)\end{array}$ \\
\hline Firm Size & $\begin{array}{l}0.0395 \\
(0.053)\end{array}$ & $\begin{array}{l}-0.0511 \\
(0.047)\end{array}$ & $\begin{array}{l}0.0258 \\
(0.059)\end{array}$ & $\begin{array}{l}-0.0897 \\
(0.067)\end{array}$ & $\begin{array}{c}0.2116^{* *} \\
(0.095)\end{array}$ & $\begin{array}{c}0.1708^{*} \\
(0.095)\end{array}$ & $\begin{array}{l}-0.0891 \\
(0.088)\end{array}$ & $\begin{array}{c}-0.1112 \\
(0.081)\end{array}$ \\
\hline Gas Hedge Ratio & $\begin{array}{c}1.0486^{* * *} \\
(0.233)\end{array}$ & $\begin{array}{c}1.0039 * * * \\
(0.208)\end{array}$ & $\begin{array}{c}0.7614^{* * *} \\
(0.201)\end{array}$ & $\begin{array}{c}0.7092 * * * \\
(0.192)\end{array}$ & $\begin{array}{c}0.4132 * * * \\
(0.150)\end{array}$ & $\begin{array}{c}0.4641^{* * *} \\
(0.165)\end{array}$ & $\begin{array}{c}1.1047^{* * *} \\
(0.209)\end{array}$ & $\begin{array}{c}1.2104^{* * *} \\
(0.226)\end{array}$ \\
\hline Gas Spot Price & $\begin{array}{l}0.0151^{*} \\
(0.009)\end{array}$ & $\begin{array}{c}0.0346^{* * *} \\
(0.009)\end{array}$ & $\begin{array}{l}0.0114 \\
(0.011)\end{array}$ & $\begin{array}{c}0.0335^{* * *} \\
(0.013)\end{array}$ & $\begin{array}{l}-0.0014 \\
(0.010)\end{array}$ & $\begin{array}{l}0.0091 \\
(0.011)\end{array}$ & $\begin{array}{l}0.0137 \\
(0.010)\end{array}$ & $\begin{array}{c}0.0390^{* * *} \\
(0.012)\end{array}$ \\
\hline Gas Volatility & $\begin{array}{c}0.0408 * * \\
(0.018)\end{array}$ & $\begin{array}{c}-0.0362^{* *} \\
(0.015)\end{array}$ & $\begin{array}{l}0.0170 \\
(0.022)\end{array}$ & $\begin{array}{c}-0.0531 * * * \\
(0.019)\end{array}$ & $\begin{array}{l}0.0431 \\
(0.041)\end{array}$ & $\begin{array}{l}-0.0036 \\
(0.034)\end{array}$ & $\begin{array}{c}0.0695^{* *} \\
(0.028)\end{array}$ & $\begin{array}{l}-0.0171 \\
(0.025)\end{array}$ \\
\hline Gas Reserves & $\begin{array}{l}0.0197 \\
(0.064)\end{array}$ & $\begin{array}{l}0.0425 \\
(0.047)\end{array}$ & $\begin{array}{l}-0.0788 \\
(0.065)\end{array}$ & $\begin{array}{l}-0.0287 \\
(0.060)\end{array}$ & $\begin{array}{c}-0.1180 \\
(0.076)\end{array}$ & $\begin{array}{l}-0.1141 \\
(0.093)\end{array}$ & $\begin{array}{l}0.1302 \\
(0.080)\end{array}$ & $\begin{array}{l}0.1144 \\
(0.069)\end{array}$ \\
\hline Gas Production Risk & $\begin{array}{l}0.0498 \\
(0.128)\end{array}$ & $\begin{array}{l}0.0441 \\
(0.121)\end{array}$ & $\begin{array}{l}0.0466 \\
(0.173)\end{array}$ & $\begin{array}{l}0.0410 \\
(0.172)\end{array}$ & $\begin{array}{l}0.2922 \\
(0.281)\end{array}$ & $\begin{array}{l}0.2526 \\
(0.302)\end{array}$ & $\begin{array}{c}0.5766^{* * * *} \\
(0.195)\end{array}$ & $\begin{array}{c}0.5745^{* * *} \\
(0.196)\end{array}$ \\
\hline Inverse Mills Ratio & $\begin{array}{l}0.0832 \\
(0.057)\end{array}$ & $\begin{array}{c}0.1253^{*} \\
(0.071)\end{array}$ & $\begin{array}{l}0.1065 \\
(0.072)\end{array}$ & $\begin{array}{l}0.1174 \\
(0.091)\end{array}$ & $\begin{array}{l}-0.0326 \\
(0.086)\end{array}$ & $\begin{array}{l}-0.1262 \\
(0.105)\end{array}$ & $\begin{array}{l}0.0850 \\
(0.152)\end{array}$ & $\begin{array}{l}-0.0036 \\
(0.152)\end{array}$ \\
\hline Constant & $\begin{array}{l}0.0007 \\
(0.279)\end{array}$ & $\begin{array}{l}-0.1358 \\
(0.277)\end{array}$ & $\begin{array}{l}0.2382 \\
(0.371)\end{array}$ & $\begin{array}{l}0.1509 \\
(0.366)\end{array}$ & $\begin{array}{l}-0.0622 \\
(0.532)\end{array}$ & $\begin{array}{l}0.0419 \\
(0.610)\end{array}$ & $\begin{array}{l}0.3424 \\
(0.527)\end{array}$ & $\begin{array}{l}0.2607 \\
(0.550)\end{array}$ \\
\hline Observations & 2,400 & 2,400 & 1,580 & 1,580 & 396 & 399 & 1,304 & 1,304 \\
\hline R-Squared & 0.2191 & 0.2580 & 0.2289 & 0.2205 & 0.2444 & 0.2973 & 0.1430 & 0.1734 \\
\hline Number of firms & 101 & 101 & 89 & 89 & 36 & 39 & 80 & 80 \\
\hline Rho & 0.4381 & 0.4562 & 0.5520 & 0.5932 & 0.5438 & 0.5254 & 0.4716 & 0.4872 \\
\hline Sigma of random effects & 0.3561 & 0.3504 & 0.5096 & 0.5287 & 0.4083 & 0.3824 & 0.4223 & 0.4182 \\
\hline Sigma of error terms & 0.4033 & 0.3825 & 0.4591 & 0.4378 & 0.3739 & 0.3634 & 0.4470 & 0.4290 \\
\hline AIC & 2363.184 & 2110.504 & 1946.326 & 1797.032 & 320.1387 & 297.4503 & 1532.211 & 1425.483 \\
\hline BIC & 2449.933 & 2203.036 & 2026.804 & 1882.875 & 379.8599 & 361.2737 & 1609.809 & 1508.255 \\
\hline
\end{tabular}

This table provides the results of the fixed effects regressions for the determinants of the weighted-average remaining maturity for the whole oil hedging portfolio, swap contracts, put options, and costless collars, respectively. All the variables are defined in Table 1. Independent variables related to oil producer characteristics (leverage ratio and its squared value, distress costs, oil production risk, debt maturity, oil reserves' life, firm size, gas hedging ratio, gas reserves, gas production risk) and oil and gas market conditions (oil spot price and its squared value, oil volatility, gas spot price, and gas volatility) are included in lagged values (first lag). The inverse Mills ratio is obtained from the firststep Heckman regression (Table A.1). Heteroskedasticity-consistent standard errors clustered at the firm level are reported in parentheses. The superscripts $* * *, * *$, and $*$ indicate statistical significance at the $1 \%, 5 \%$, and $10 \%$ levels, respectively. 
Table 7

Determinants of the early termination of hedging contracts

\begin{tabular}{|c|c|c|c|c|c|c|}
\hline & $(1)$ & $(2)$ & (3) & (4) & (5) & (6) \\
\hline Variables & Swap Contracts & Swap Contracts & Put Options & Put Options & Costless Collars & Costless Collars \\
\hline Leverage & $\begin{array}{c}-4.7386 * * \\
(1.876)\end{array}$ & $\begin{array}{c}-5.0008 * * * \\
(1.901)\end{array}$ & $\begin{array}{l}-1.1806 \\
(4.181)\end{array}$ & $\begin{array}{l}-0.4433 \\
(4.035)\end{array}$ & $\begin{array}{l}6.6384 \\
(4.563)\end{array}$ & $\begin{array}{l}5.1647 \\
(3.362)\end{array}$ \\
\hline Leverage Squared & $\begin{array}{c}3.0929 * * * \\
(1.172)\end{array}$ & $\begin{array}{c}3.0707 * * \\
(1.215)\end{array}$ & $\begin{array}{l}0.4135 \\
(4.124)\end{array}$ & $\begin{array}{l}0.0021 \\
(3.941)\end{array}$ & $\begin{array}{l}-4.5736 \\
(3.915)\end{array}$ & $\begin{array}{l}-3.4904 \\
(2.702)\end{array}$ \\
\hline Distress Costs & $\begin{array}{c}-0.0893 \\
(0.061)\end{array}$ & $\begin{array}{l}-0.0928 \\
(0.070)\end{array}$ & $\begin{array}{l}-0.0021 \\
(0.027)\end{array}$ & $\begin{array}{l}0.0070 \\
(0.028)\end{array}$ & $\begin{array}{r}-0.0491 \\
(0.039)\end{array}$ & $\begin{array}{l}-0.0683 \\
(0.044)\end{array}$ \\
\hline Oil Spot Price & & $\begin{array}{c}-0.0423^{*} \\
(0.024)\end{array}$ & & $\begin{array}{l}-0.0125 \\
(0.049)\end{array}$ & & $\begin{array}{c}-0.0906 * * * \\
(0.025)\end{array}$ \\
\hline Spot Squared & & $\begin{array}{l}0.0001 \\
(0.000)\end{array}$ & & $\begin{array}{l}0.0002 \\
(0.000)\end{array}$ & & $\begin{array}{c}0.0005^{* * *} \\
(0.000)\end{array}$ \\
\hline Oil Volatility & $\begin{array}{c}0.0793 \\
(0.056)\end{array}$ & & $\begin{array}{c}0.1397 * * \\
(0.069)\end{array}$ & & $\begin{array}{l}0.0040 \\
(0.076)\end{array}$ & \\
\hline Remaining Maturity & $\begin{array}{l}0.0992 \\
(0.193)\end{array}$ & & $\begin{array}{l}0.5535 \\
(0.497)\end{array}$ & & $\begin{array}{l}0.1146 \\
(0.249)\end{array}$ & \\
\hline Moneyness Indicator & & $\begin{array}{c}-0.3384^{* *} \\
(0.159)\end{array}$ & & $\begin{array}{l}-0.0025 \\
(0.320)\end{array}$ & & $\begin{array}{l}-0.1064 \\
(0.158)\end{array}$ \\
\hline Oil Production Risk & $\begin{array}{c}-2.5845^{* *} \\
(1.253)\end{array}$ & $\begin{array}{c}-2.7317^{* *} \\
(1.317)\end{array}$ & $\begin{array}{c}0.3522 \\
(1.295)\end{array}$ & $\begin{array}{l}0.4191 \\
(1.154)\end{array}$ & $\begin{array}{r}-0.0349 \\
(0.861)\end{array}$ & $\begin{array}{l}-0.4532 \\
(0.843)\end{array}$ \\
\hline Debt Maturity & $\begin{array}{c}-0.0039 \\
(0.101)\end{array}$ & $\begin{array}{l}0.0032 \\
(0.105)\end{array}$ & $\begin{array}{c}-0.2689 * * \\
(0.116)\end{array}$ & $\begin{array}{c}-0.2444^{* *} \\
(0.110)\end{array}$ & $\begin{array}{l}0.0005 \\
(0.090)\end{array}$ & $\begin{array}{l}0.0746 \\
(0.099)\end{array}$ \\
\hline Oil Reserves Life & $\begin{array}{l}0.0069 \\
(0.024)\end{array}$ & $\begin{array}{l}-0.0021 \\
(0.029)\end{array}$ & $\begin{array}{c}-0.1759 * \\
(0.093)\end{array}$ & $\begin{array}{c}-0.1410^{* *} \\
(0.071)\end{array}$ & $\begin{array}{l}0.0142 \\
(0.025)\end{array}$ & $\begin{array}{l}0.0028 \\
(0.035)\end{array}$ \\
\hline Firm Size & $\begin{array}{l}-0.1204 \\
(0.265)\end{array}$ & $\begin{array}{l}0.1955 \\
(0.345)\end{array}$ & $\begin{array}{c}-1.0621^{* * *} \\
(0.268)\end{array}$ & $\begin{array}{c}-0.9979 * * * \\
(0.349)\end{array}$ & $\begin{array}{l}-0.0655 \\
(0.248)\end{array}$ & $\begin{array}{l}0.3360 \\
(0.264)\end{array}$ \\
\hline Gas Hedge Ratio & $\begin{array}{c}-8.1605^{* * *} \\
(2.470)\end{array}$ & $\begin{array}{c}-5.9258^{* *} \\
(2.665)\end{array}$ & $\begin{array}{l}-0.6694 \\
(5.359)\end{array}$ & $\begin{array}{l}-0.8931 \\
(6.840)\end{array}$ & $\begin{array}{l}-4.5820 \\
(3.288)\end{array}$ & $\begin{array}{l}-1.3428 \\
(2.394)\end{array}$ \\
\hline Gas Spot Price & $\begin{array}{r}-0.1582 \\
(0.098)\end{array}$ & $\begin{array}{c}-0.0246 \\
(0.095)\end{array}$ & $\begin{array}{l}0.0679 \\
(0.144)\end{array}$ & $\begin{array}{r}-0.0369 \\
(0.168)\end{array}$ & $\begin{array}{r}-0.0507 \\
(0.084)\end{array}$ & $\begin{array}{l}0.0638 \\
(0.081)\end{array}$ \\
\hline Gas Volatility & $\begin{array}{l}-0.5416 \\
(0.495)\end{array}$ & $\begin{array}{l}-0.4432 \\
(0.479)\end{array}$ & $\begin{array}{l}-0.0018 \\
(0.551)\end{array}$ & $\begin{array}{l}0.2703 \\
(0.687)\end{array}$ & $\begin{array}{l}0.2566 \\
(0.316)\end{array}$ & $\begin{array}{l}0.3459 \\
(0.333)\end{array}$ \\
\hline Gas Reserves & $\begin{array}{l}0.1700 \\
(0.268)\end{array}$ & $\begin{array}{l}-0.1025 \\
(0.321)\end{array}$ & $\begin{array}{c}0.8023^{* *} \\
(0.375)\end{array}$ & $\begin{array}{c}0.7934 * \\
(0.411)\end{array}$ & $\begin{array}{l}-0.2119 \\
(0.205)\end{array}$ & $\begin{array}{c}-0.4526^{* *} \\
(0.227)\end{array}$ \\
\hline Gas Production Risk & $\begin{array}{l}0.0864 \\
(1.028)\end{array}$ & $\begin{array}{r}-0.0110 \\
(0.897)\end{array}$ & $\begin{array}{c}-3.5684 * * \\
(1.542)\end{array}$ & $\begin{array}{c}-3.5351^{* *} \\
(1.463)\end{array}$ & $\begin{array}{l}-1.5111 \\
(1.028)\end{array}$ & $\begin{array}{l}-1.0409 \\
(1.011)\end{array}$ \\
\hline Constant & $\begin{array}{r}-0.4017 \\
(1.072)\end{array}$ & $\begin{array}{l}0.1445 \\
(1.310)\end{array}$ & $\begin{array}{l}1.7008 \\
(1.564)\end{array}$ & $\begin{array}{l}2.0131 \\
(1.541)\end{array}$ & $\begin{array}{c}-3.7425^{* * *} \\
(1.530)\end{array}$ & $\begin{array}{l}-2.5637 \\
(1.601)\end{array}$ \\
\hline Observations & 1,654 & 1,654 & 430 & 430 & 1,389 & 1,389 \\
\hline Number of firms & 89 & 89 & 40 & 40 & 80 & 80 \\
\hline Log Likelihood & -206.9945 & -203.5725 & -73.0966 & -73.4411 & -195.7764 & -186.7756 \\
\hline AIC & 445.989 & 441.1449 & 178.1932 & 180.8822 & 423.5527 & 407.5511 \\
\hline $\mathrm{BIC}$ & 532.5643 & 533.1311 & 243.2138 & 249.9665 & 507.3342 & 496.5689 \\
\hline
\end{tabular}

This table provides the results of random effects logit regressions of the determinants of the early termination of swap contracts, put options, and costless collars, respectively. The dependent variable is a dummy variable that takes the value of one when there is an early termination of the hedging contract and zero otherwise. All the variables are defined in Table 1 . Independent variables related to oil producer characteristics (leverage ratio and its squared value, distress costs, oil production risk, debt maturity, oil reserves' life, firm size, gas hedging ratio, gas reserves, gas production risk), oil and gas market conditions (oil spot price and its squared value, oil volatility, gas spot price, and gas volatility), and hedging contract features (moneyness indicator and remaining maturity) are included in lagged values (first lag). Heteroskedasticity-consistent standard errors clustered at the firm level are reported in parentheses. The superscripts ***, **, and * indicate statistical significance at the 1\%, 5\%, and 10\% levels, respectively. 
Table 8

Real implications of short-term versus long-term hedging maturities

\begin{tabular}{|c|c|c|}
\hline & $(1)$ & (2) \\
\hline & & \\
\hline Variables & Treated & Untreated \\
\hline ROA & -0.0212 & $0.5792 * *$ \\
\hline & $(0.192)$ & $(0.226)$ \\
\hline Investment Opportunities & 0.0195 & 0.3379 \\
\hline & $(0.078)$ & $(0.297)$ \\
\hline Leverage & 0.0556 & -0.0035 \\
\hline & $(0.107)$ & $(0.123)$ \\
\hline Liquidity & $0.0684 * * *$ & 0.0719 \\
\hline & $(0.026)$ & $(0.046)$ \\
\hline Dividend Payout & $0.1697 * * *$ & 0.0556 \\
\hline & $(0.047)$ & $(0.082)$ \\
\hline Oil Reserves & -0.0313 & -0.0289 \\
\hline & $(0.023)$ & $(0.046)$ \\
\hline Inst ownership & 0.0220 & -0.0313 \\
\hline & $(0.094)$ & $(0.095)$ \\
\hline Geo Diversification & 0.0972 & 0.0002 \\
\hline & $(0.104)$ & $(0.121)$ \\
\hline Oil Volatility & $-0.0265 * * *$ & $-0.0279 * * *$ \\
\hline & $(0.004)$ & $(0.008)$ \\
\hline Oil Spot Price & $-0.0027 * *$ & -0.0021 \\
\hline & $(0.001)$ & $(0.004)$ \\
\hline Oil Production Risk & 0.0509 & -0.1467 \\
\hline & $(0.085)$ & $(0.114)$ \\
\hline Gas Hedge Ratio & $-0.6577 * *$ & -0.1392 \\
\hline & $(0.278)$ & $(0.973)$ \\
\hline Gas Spot Price & $0.0246^{* * *}$ & $0.0430^{* * *}$ \\
\hline & $(0.005)$ & $(0.011)$ \\
\hline Gas Volatility & -0.0263 & -0.0346 \\
\hline & $(0.018)$ & $(0.030)$ \\
\hline Gas Reserves & $-0.0637 * * *$ & 0.0114 \\
\hline & $(0.018)$ & $(0.035)$ \\
\hline Gas Production Risk & $-0.1921 * *$ & $0.2565 *$ \\
\hline & $(0.079)$ & $(0.136)$ \\
\hline Inverse Mills Ratio & $-0.3374 * * *$ & $-0.3183^{*}$ \\
\hline & $(0.102)$ & $(0.164)$ \\
\hline 2008 & 0.0531 & 0.0408 \\
\hline & $(0.066)$ & (0.195) \\
\hline 2009 & $-0.1124 * *$ & 0.0750 \\
\hline & $(0.051)$ & $(0.083)$ \\
\hline Constant & $1.3600^{* * *}$ & $0.5277^{*}$ \\
\hline & $(0.238)$ & $(0.303)$ \\
\hline$\overline{\text { ATE }}$ & & \\
\hline & & \\
\hline Observations & & \\
\hline This table provides the rest & he essential & for the real ir \\
\hline of using long-term versus $\mathrm{s}$ & the Tobin's & atio of the $n$ \\
\hline of equity plus the book valı & book value $\mathrm{c}$ & variables are \\
\hline Table 1. Independent variab & ent opportuniti & uidity, divic \\
\hline $\begin{array}{l}\text { oil reserves, institutional ov } \\
\text { and oil and gas market conc }\end{array}$ & $\begin{array}{l}\text { sk, gas hedge } 1 \\
\text { gas volatility) }\end{array}$ & $\begin{array}{l}\text { d gas produ } \\
\text { d values (firs }\end{array}$ \\
\hline inverse Mills ratio is from th & ATE stands fo & ent effect. Tr \\
\hline of long-term hedging & g positions. $\mathrm{E}$ & d errors clus \\
\hline irm level using 500 repetiti & , dilu & de tu \\
\hline
\end{tabular}


Figure 1: Non-monotonic relationship between oil hedging maturity and the leverage ratio

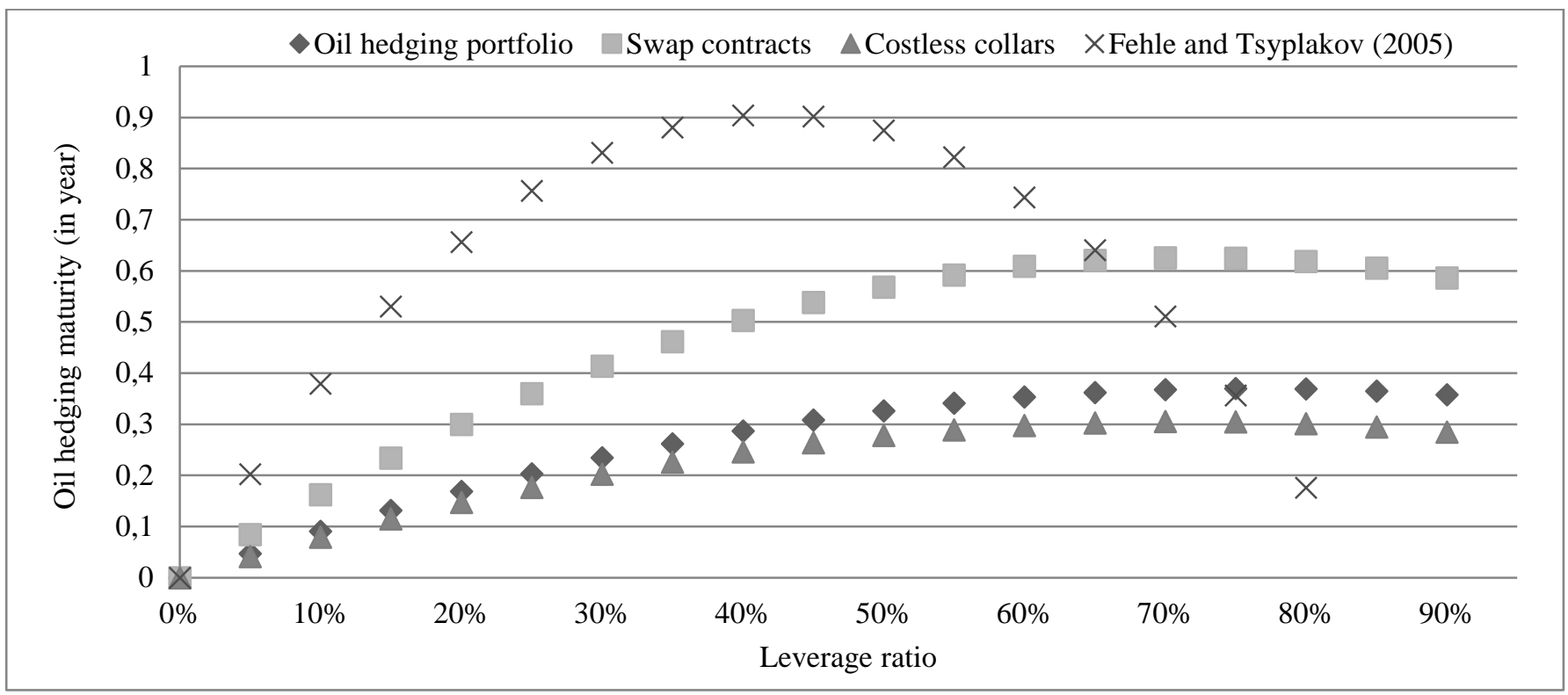

This figure illustrates the relationship between hedging maturity and the leverage ratio: Maturity $=\alpha \times$ Leverage $+\beta \times$ Lverage ${ }^{2}+\sum$ Controls, with $\alpha$ and $\beta$ calculated from the estimation of the fixed effects regressions reported in Table 6. The coefficients $\alpha$ and $\beta$, respectively, equal 0.9724 and -0.6388 for the oil hedging portfolio, 1.7418 and -1.2114 for swap contracts, and 0.8549 and -0.5928 for costless collars (see Table 6 , columns 1 , 3, and 8). For Fehle and Tsyplakov (2005), $\alpha$ and $\beta$ equal 4.30 and -5.10 (see Table 16, pp. 41 from Fehle and Tsyplakov, 2005).

Figure 2: Non-monotonic relationship between oil hedging maturity and oil spot prices

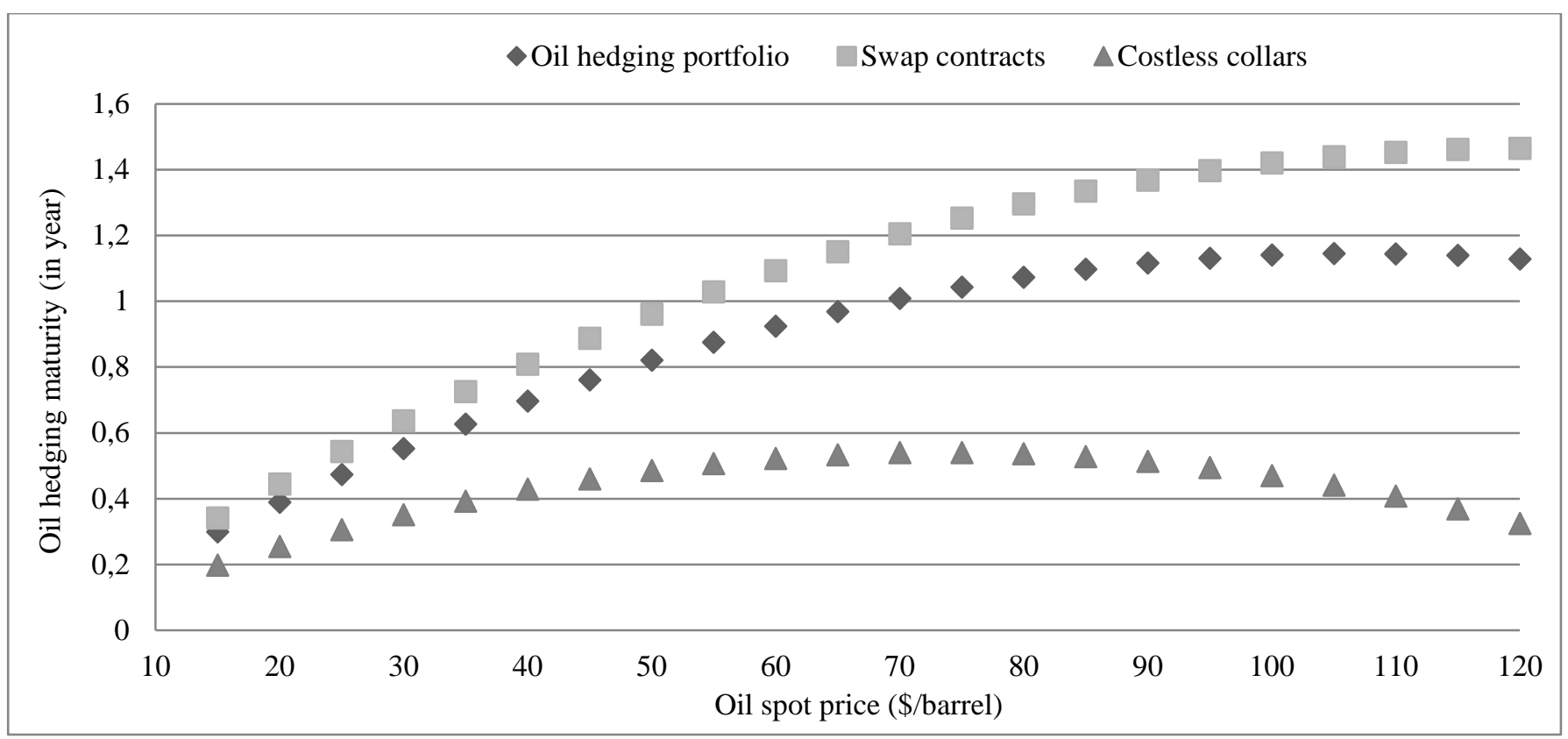

This figure illustrates the relationship between hedging maturity and oil spot prices: Maturity $=\alpha \times$ Oil spot price $+\beta \times$ Oil spot price ${ }^{2}+\sum$ Controls, with $\alpha$ and $\beta$ calculated from the estimation of the fixed effects regressions reported in Table 6. The coefficients $\alpha$ and $\beta$, respectively, equal 0.0214 and -0.0001 for the oil hedging portfolio, 0.0242 and -0.0001 for swap contracts, and 0.0147 and -0.0001 for costless collars (see Table 6 , columns 2 , 4, and 8). 
Figure 3: Estimated MTEs



This figure plots the estimated MTE for firm value, measured by the Tobin's $q$, over the common support of the unobserved resistance among US oil producers to use long-term hedging maturities. Average treatment effect (ATE) and 95\% normal confidence interval are also plotted. 


\section{Dynamic corporate risk management: Motivations and real implications}

This revised version: August , 2017

\section{Online appendix}

\section{A. Tables}

Table A.1: Determinants of the oil hedging decision

\begin{tabular}{|c|c|}
\hline Variables & Oil Hedge \\
\hline Firm Size & $\begin{array}{c}0.1828 * * * \\
(0.065)\end{array}$ \\
\hline Tax Save & $\begin{array}{c}0.9667^{*} \\
(0.584)\end{array}$ \\
\hline DTD & $\begin{array}{c}-0.1142^{* *} \\
(0.055)\end{array}$ \\
\hline Liquidity & $\begin{array}{c}-0.1818 * * * \\
(0.047)\end{array}$ \\
\hline Dvd Payout & $\begin{array}{l}-0.1866 \\
(0.210)\end{array}$ \\
\hline Investment Opportunities & $\begin{array}{c}0.1332 * * * \\
(0.044)\end{array}$ \\
\hline Institutional Ownership & $\begin{array}{c}0.7746 * * * \\
(0.299)\end{array}$ \\
\hline Geographic Diversification & $\begin{array}{c}-0.7193 * \\
(0.393)\end{array}$ \\
\hline CEO Ownership & $\begin{array}{c}2.2290 * * \\
(0.882)\end{array}$ \\
\hline Constant & $\begin{array}{c}-1.6489 * * * \\
(0.356)\end{array}$ \\
\hline Observations & 5,384 \\
\hline Pseudo-R squared & 0.2254 \\
\hline Chi-squared & 305.1534 \\
\hline Significance & 0.0000 \\
\hline AIC & 5879.909 \\
\hline $\mathrm{BIC}$ & 6288.563 \\
\hline
\end{tabular}

This table reports the coefficient estimates of the probit model. The dependent variable is the hedging decision dummy variable, which takes the value of one if the oil producer has any oil hedging position for the quarter and zero otherwise. All the variables are defined in Table 1. The independent variables are included in lagged values (first lag). Heteroscedasticity-consistent standard errors clustered at the firm level are reported in parentheses. Time dummies for quarters are not reported. The superscripts $* * *$, $* *$, and * indicate statistical significance at the $1 \%, 5 \%$, and $10 \%$ levels, respectively. 
Table A.2: Oil hedging maturity structure-Alternative specification



This table provides the results of the fixed effects regressions for the determinants of remaining maturity for the oil hedging portfolio, swap contracts, put options, and costless collars, respectively. For each firm-quarter with oil hedging activity, this maturity is determined by taking the maximum horizon of hedging without weighting by the hedged quantity. All the variables are defined in Table 1. Independent variables related to oil producer characteristics (leverage ratio and its squared value, distress costs, oil production risk, debt maturity, oil reserves' life, firm size, gas hedging ratio, gas reserves, gas production risk), and oil and gas market conditions (oil spot price and its squared value, oil volatility, gas spot price, and gas volatility) are included in lagged values (first lag).The inverse Mills ratio is from the first-step Heckman regression (Table A.1). Heteroskedasticityconsistent standard errors clustered at the firm level are reported in parentheses. The superscripts ***, ${ }^{* *}$, and * indicate statistical significance at the $1 \%, 5 \%$, and $10 \%$ levels, respectively. 
Table A.3: Determinants of the early termination of hedging contracts-Alternative specification for the remaining maturity

\begin{tabular}{|c|c|c|c|c|c|c|}
\hline & (1) & (2) & (3) & (4) & (5) & (6) \\
\hline Variables & Swap Contracts & Swap Contracts & Put Options & Put Options & Costless Collars & Costless Collars \\
\hline Leverage & $\begin{array}{c}-4.5693^{* *} \\
(1.918)\end{array}$ & $\begin{array}{c}-5.0008 * * * \\
(1.901)\end{array}$ & $\begin{array}{l}-1.6812 \\
(3.550)\end{array}$ & $\begin{array}{l}-0.4433 \\
(4.035)\end{array}$ & $\begin{array}{l}6.4126 \\
(3.944)\end{array}$ & $\begin{array}{l}5.1647 \\
(3.362)\end{array}$ \\
\hline Leverage Squared & $\begin{array}{c}2.9672 * * \\
(1.185)\end{array}$ & $\begin{array}{c}3.0707 * * \\
(1.215)\end{array}$ & $\begin{array}{l}0.9361 \\
(3.621)\end{array}$ & $\begin{array}{l}0.0021 \\
(3.941)\end{array}$ & $\begin{array}{l}-4.3693 \\
(3.342)\end{array}$ & $\begin{array}{l}-3.4904 \\
(2.702)\end{array}$ \\
\hline Distress Costs & $\begin{array}{c}-0.0931 \\
(0.065)\end{array}$ & $\begin{array}{l}-0.0928 \\
(0.070)\end{array}$ & $\begin{array}{l}0.0073 \\
(0.029)\end{array}$ & $\begin{array}{l}0.0070 \\
(0.028)\end{array}$ & $\begin{array}{l}-0.0607 \\
(0.045)\end{array}$ & $\begin{array}{r}-0.0683 \\
(0.044)\end{array}$ \\
\hline Oil Spot Price & & $\begin{array}{c}-0.0423^{*} \\
(0.024)\end{array}$ & & $\begin{array}{r}-0.0125 \\
(0.049)\end{array}$ & & $\begin{array}{c}-0.0906 * * * \\
(0.025)\end{array}$ \\
\hline Spot Squared & & $\begin{array}{l}0.0001 \\
(0.000)\end{array}$ & & $\begin{array}{l}0.0002 \\
(0.000)\end{array}$ & & $\begin{array}{c}0.0005^{* * * *} \\
(0.000)\end{array}$ \\
\hline Oil Volatility & $\begin{array}{l}0.0876 \\
(0.056)\end{array}$ & & $\begin{array}{c}0.1483 * * \\
(0.068)\end{array}$ & & $\begin{array}{l}0.0050 \\
(0.084)\end{array}$ & \\
\hline Remaining Maturity & $\begin{array}{l}-0.2852 \\
(0.195)\end{array}$ & & $\begin{array}{c}-0.7262^{* *} \\
(0.334)\end{array}$ & & $\begin{array}{c}-0.5233^{* *} \\
(0.209)\end{array}$ & \\
\hline Moneyness Indicator & & $\begin{array}{c}-0.3384 * * \\
(0.159)\end{array}$ & & $\begin{array}{l}-0.0025 \\
(0.320)\end{array}$ & & $\begin{array}{l}-0.1064 \\
(0.158)\end{array}$ \\
\hline Oil Production Risk & $\begin{array}{c}-2.6918 * * \\
(1.264)\end{array}$ & $\begin{array}{c}-2.7317^{* *} \\
(1.317)\end{array}$ & $\begin{array}{l}0.4118 \\
(1.124)\end{array}$ & $\begin{array}{l}0.4191 \\
(1.154)\end{array}$ & $\begin{array}{c}-0.1935 \\
(0.833)\end{array}$ & $\begin{array}{r}-0.4532 \\
(0.843)\end{array}$ \\
\hline Debt Maturity & $\begin{array}{r}-0.0010 \\
(0.100)\end{array}$ & $\begin{array}{l}0.0032 \\
(0.105)\end{array}$ & $\begin{array}{c}-0.2643^{* *} \\
(0.126)\end{array}$ & $\begin{array}{c}-0.2444^{* *} \\
(0.110)\end{array}$ & $\begin{array}{l}0.0011 \\
(0.083)\end{array}$ & $\begin{array}{l}0.0746 \\
(0.099)\end{array}$ \\
\hline Oil Reserves Life & $\begin{array}{l}0.0149 \\
(0.024)\end{array}$ & $\begin{array}{l}-0.0021 \\
(0.029)\end{array}$ & $\begin{array}{l}-0.1192 \\
(0.077)\end{array}$ & $\begin{array}{c}-0.1410^{* *} \\
(0.071)\end{array}$ & $\begin{array}{l}0.0131 \\
(0.023)\end{array}$ & $\begin{array}{l}0.0028 \\
(0.035)\end{array}$ \\
\hline Firm Size & $\begin{array}{l}-0.0745 \\
(0.246)\end{array}$ & $\begin{array}{l}0.1955 \\
(0.345)\end{array}$ & $\begin{array}{c}-1.0116^{* * *} \\
(0.249)\end{array}$ & $\begin{array}{c}-0.9979 * * * \\
(0.349)\end{array}$ & $\begin{array}{l}0.0458 \\
(0.246)\end{array}$ & $\begin{array}{l}0.3360 \\
(0.264)\end{array}$ \\
\hline Gas Hedge Ratio & $\begin{array}{c}-6.9665 * * * \\
(2.519)\end{array}$ & $\begin{array}{c}-5.9258^{* *} \\
(2.665)\end{array}$ & $\begin{array}{l}0.7548 \\
(5.665)\end{array}$ & $\begin{array}{l}-0.8931 \\
(6.840)\end{array}$ & $\begin{array}{l}-2.4342 \\
(2.922)\end{array}$ & $\begin{array}{l}-1.3428 \\
(2.394)\end{array}$ \\
\hline Gas Spot Price & $\begin{array}{l}-0.1382 \\
(0.092)\end{array}$ & $\begin{array}{l}-0.0246 \\
(0.095)\end{array}$ & $\begin{array}{l}0.0914 \\
(0.139)\end{array}$ & $\begin{array}{l}-0.0369 \\
(0.168)\end{array}$ & $\begin{array}{r}-0.0490 \\
(0.079)\end{array}$ & $\begin{array}{c}0.0638 \\
(0.081)\end{array}$ \\
\hline Gas Volatility & $\begin{array}{l}-0.5012 \\
(0.479)\end{array}$ & $\begin{array}{l}-0.4432 \\
(0.479)\end{array}$ & $\begin{array}{l}0.0233 \\
(0.532)\end{array}$ & $\begin{array}{l}0.2703 \\
(0.687)\end{array}$ & $\begin{array}{l}0.3363 \\
(0.307)\end{array}$ & $\begin{array}{l}0.3459 \\
(0.333)\end{array}$ \\
\hline Gas Reserves & $\begin{array}{l}0.1469 \\
(0.248)\end{array}$ & $\begin{array}{l}-0.1025 \\
(0.321)\end{array}$ & $\begin{array}{c}0.8720 * * \\
(0.380)\end{array}$ & $\begin{array}{c}0.7934 * \\
(0.411)\end{array}$ & $\begin{array}{l}-0.2575 \\
(0.212)\end{array}$ & $\begin{array}{c}-0.4526^{* *} \\
(0.227)\end{array}$ \\
\hline Gas Production Risk & $\begin{array}{l}0.2378 \\
(1.001)\end{array}$ & $\begin{array}{l}-0.0110 \\
(0.897)\end{array}$ & $\begin{array}{c}-3.2758^{* *} \\
(1.336)\end{array}$ & $\begin{array}{c}-3.5351^{* *} \\
(1.463)\end{array}$ & $\begin{array}{l}-1.2555 \\
(0.950)\end{array}$ & $\begin{array}{l}-1.0409 \\
(1.011)\end{array}$ \\
\hline Constant & $\begin{array}{c}-0.4326 \\
(1.095)\end{array}$ & $\begin{array}{c}0.1445 \\
(1.310)\end{array}$ & $\begin{array}{l}1.6581 \\
(1.324)\end{array}$ & $\begin{array}{l}2.0131 \\
(1.541)\end{array}$ & $\begin{array}{c}-3.5588^{* *} \\
(1.449)\end{array}$ & $\begin{array}{l}-2.5637 \\
(1.601)\end{array}$ \\
\hline Observations & 1,654 & 1,654 & 430 & 430 & 1,389 & 1,389 \\
\hline Number of firms & 89 & 89 & 40 & 40 & 80 & 80 \\
\hline Log Likelihood & -205.6486 & -203.5725 & -72.2952 & -73.4411 & -192.5772 & -186.7756 \\
\hline AIC & 443.2971 & 441.1449 & 176.5903 & 180.8822 & 417.1543 & 407.5511 \\
\hline BIC & 529.8723 & 533.1311 & 241.6109 & 249.9665 & 500.9357 & 496.5689 \\
\hline
\end{tabular}

This table provides the results of random effects logit regressions of the determinants of the early termination of swap contracts, put options, and costless collars, respectively. The dependent variable is a dummy variable that takes the value of one when there is an early termination of the hedging contract and zero otherwise. The remaining maturity is calculated without weighting by the hedged quantities. All the variables are defined in Table 1. Independent variables related to oil producer characteristics (leverage ratio and its squared value, distress costs, oil production risk, debt maturity, oil reserves' life, firm size, gas hedging ratio, gas reserves, gas production risk), oil and gas market conditions (oil spot price and its squared value, oil volatility, gas spot price, and gas volatility), and hedging contract features (moneyness indicator and remaining maturity) are included in lagged values (first lag). Heteroskedasticity-consistent standard errors clustered at the firm level are reported in parentheses. The superscripts $* * *, * *$, and $*$ indicate statistical significance at the $1 \%, 5 \%$, and $10 \%$ levels, respectively. 
Table A.4: First-step of the essential heterogeneity models

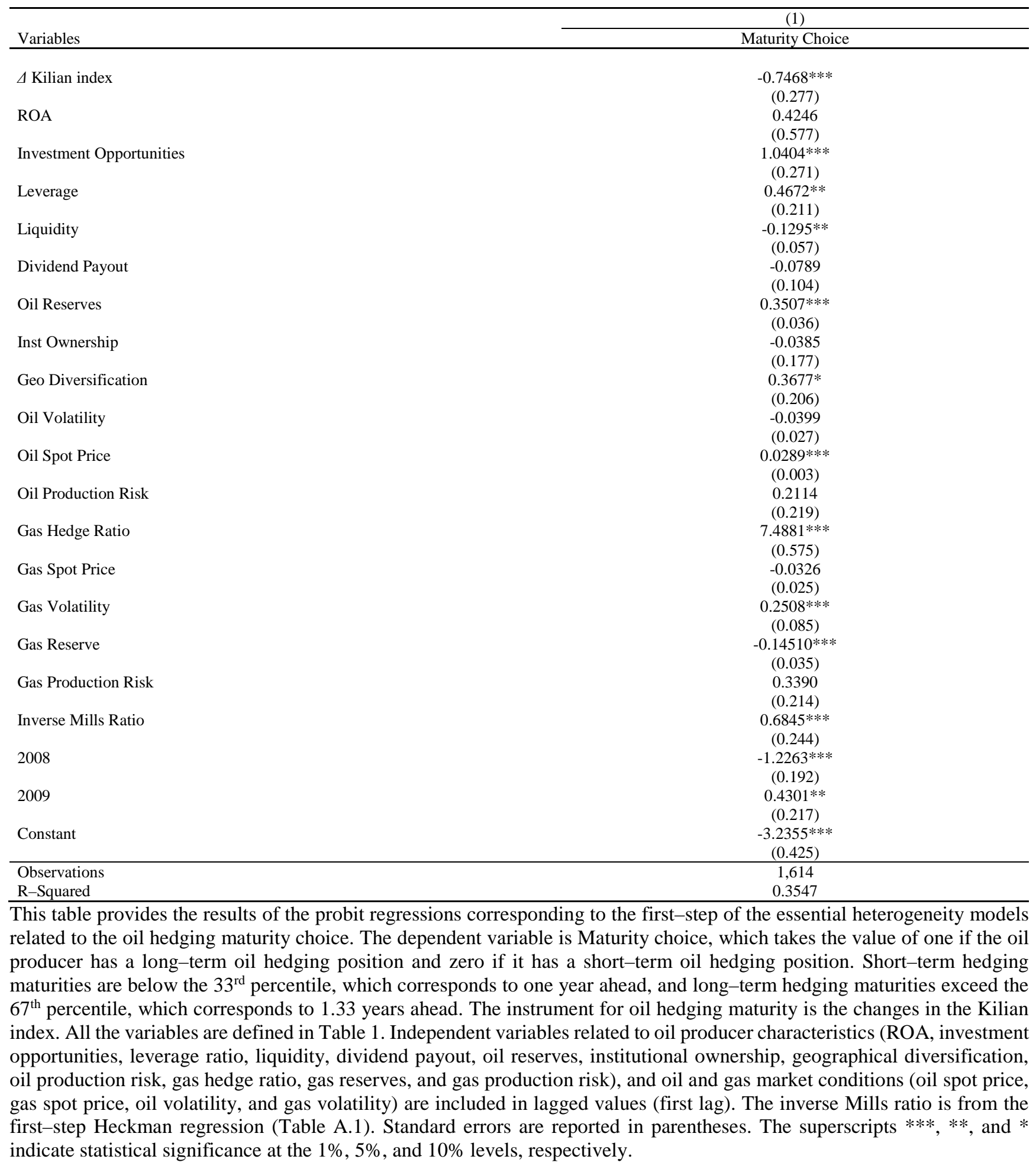


Table A.5: Estimated MTEs

\begin{tabular}{|c|c|c|c|c|c|c|c|}
\hline (1) & (2) & (3) & (4) & (5) & (6) & (7) & (8) \\
\hline $\mathrm{U}_{0}$ & Tobin's $q$ & $\mathbb{N}_{b}$ & Tobin's $q$ & $\mathbb{B}_{b}$ & Tobin's $q$ & $\mathbb{U}_{b}$ & Tobin's $q$ \\
\hline$u 1$ & $\begin{array}{c}-0.5159 \\
(0.739)\end{array}$ & $u 26$ & $\begin{array}{l}-0.0020 \\
(0.340)\end{array}$ & u51 & $\begin{array}{l}0.2020 \\
(0.197)\end{array}$ & $u 76$ & $\begin{array}{c}0.4100^{* * *} \\
(0.124)\end{array}$ \\
\hline$u 2$ & $\begin{array}{r}-0.4327 \\
(0.673)\end{array}$ & $u 27$ & $\begin{array}{l}0.0073 \\
(0.333)\end{array}$ & u52 & $\begin{array}{l}0.2097 \\
(0.192)\end{array}$ & $u 77$ & $\begin{array}{c}0.4200^{* * *} \\
(0.125)\end{array}$ \\
\hline u3 & $\begin{array}{l}-0.3799 \\
(0.632)\end{array}$ & $u 28$ & $\begin{array}{l}0.0164 \\
(0.326)\end{array}$ & u53 & $\begin{array}{l}0.2174 \\
(0.187)\end{array}$ & $u 78$ & $\begin{array}{c}0.4302^{* * *} \\
(0.126)\end{array}$ \\
\hline$u 4$ & $\begin{array}{l}-0.3401 \\
(0.601)\end{array}$ & $u 29$ & $\begin{array}{c}0.0254 \\
(0.320)\end{array}$ & $u 54$ & $\begin{array}{c}0.2250 \\
(0.183)\end{array}$ & $u 79$ & $\begin{array}{c}0.4406 * * * \\
(0.128)\end{array}$ \\
\hline u5 & $\begin{array}{l}-0.3078 \\
(0.575)\end{array}$ & u30 & $\begin{array}{c}0.0343 \\
(0.313)\end{array}$ & u55 & $\begin{array}{c}0.2328 \\
(0.178)\end{array}$ & $u 80$ & $\begin{array}{c}0.4514^{* * *} \\
(0.131)\end{array}$ \\
\hline$u 6$ & $\begin{array}{c}-0.2803 \\
(0.554)\end{array}$ & u31 & $\begin{array}{c}0.0430 \\
(0.307)\end{array}$ & u56 & $\begin{array}{c}0.2405 \\
(0.174)\end{array}$ & $u 81$ & $\begin{array}{c}0.4624 * * * \\
(0.135)\end{array}$ \\
\hline$u 7$ & $\begin{array}{l}-0.2562 \\
(0.535)\end{array}$ & u32 & $\begin{array}{l}0.0516 \\
(0.301)\end{array}$ & $u 57$ & $\begin{array}{c}0.2482 \\
(0.170)\end{array}$ & u82 & $\begin{array}{c}0.4739 * * * \\
(0.139)\end{array}$ \\
\hline$u 8$ & $\begin{array}{r}-0.2346 \\
(0.518)\end{array}$ & u33 & $\begin{array}{c}0.0601 \\
(0.294)\end{array}$ & $u 58$ & $\begin{array}{c}0.2560 \\
(0.165)\end{array}$ & $u 83$ & $\begin{array}{c}0.4857 * * * \\
(0.143)\end{array}$ \\
\hline u9 & $\begin{array}{l}-0.2150 \\
(0.503)\end{array}$ & u34 & $\begin{array}{l}0.0684 \\
(0.288)\end{array}$ & u59 & $\begin{array}{l}0.2639 \\
(0.161)\end{array}$ & $u 84$ & $\begin{array}{c}0.4980^{* * *} \\
(0.148)\end{array}$ \\
\hline u10 & $\begin{array}{l}-0.1969 \\
(0.489)\end{array}$ & u35 & $\begin{array}{c}0.0767 \\
(0.282)\end{array}$ & $u 60$ & $\begin{array}{c}0.2717^{*} \\
(0.157)\end{array}$ & $u 85$ & $\begin{array}{c}0.5108 * * * \\
(0.154)\end{array}$ \\
\hline u11 & $\begin{array}{l}-0.1801 \\
(0.476)\end{array}$ & u36 & $\begin{array}{c}0.0849 \\
(0.276)\end{array}$ & $u 61$ & $\begin{array}{c}0.2797 * \\
(0.153)\end{array}$ & u86 & $\begin{array}{c}0.5242 * * * \\
(0.161)\end{array}$ \\
\hline u12 & $\begin{array}{l}-0.1644 \\
(0.464)\end{array}$ & u37 & $\begin{array}{c}0.0931 \\
(0.271)\end{array}$ & u62 & $\begin{array}{c}0.2877^{*} \\
(0.150)\end{array}$ & $u 87$ & $\begin{array}{c}0.5383 * * * \\
(0.169)\end{array}$ \\
\hline u13 & $\begin{array}{r}-0.1495 \\
(0.452)\end{array}$ & u38 & $\begin{array}{l}0.1011 \\
(0.265)\end{array}$ & $u 63$ & $\begin{array}{c}0.2957 * * \\
(0.146)\end{array}$ & $u 88$ & $\begin{array}{c}0.5531^{* * *} \\
(0.177)\end{array}$ \\
\hline u14 & $\begin{array}{r}-0.1355 \\
(0.441)\end{array}$ & u39 & $\begin{array}{c}0.1091 \\
(0.259)\end{array}$ & $u 64$ & $\begin{array}{c}0.3038 * * \\
(0.143)\end{array}$ & u89 & $\begin{array}{c}0.5689 * * * \\
(0.186)\end{array}$ \\
\hline$u 15$ & $\begin{array}{l}-0.1221 \\
(0.431)\end{array}$ & $u 40$ & $\begin{array}{l}0.1170 \\
(0.254)\end{array}$ & $u 65$ & $\begin{array}{c}0.3120 * * \\
(0.139)\end{array}$ & u90 & $\begin{array}{c}0.5857 * * * \\
(0.197)\end{array}$ \\
\hline u16 & $\begin{array}{c}-0.1092 \\
(0.421)\end{array}$ & $u 41$ & $\begin{array}{l}0.1249 \\
(0.248)\end{array}$ & $u 66$ & $\begin{array}{c}0.3203^{* *} \\
(0.136)\end{array}$ & u91 & $\begin{array}{c}0.6037 * * * \\
(0.208)\end{array}$ \\
\hline$u 17$ & $\begin{array}{l}-0.0969 \\
(0.412)\end{array}$ & $u 42$ & $\begin{array}{l}0.1327 \\
(0.243)\end{array}$ & $u 67$ & $\begin{array}{c}0.3287 * * \\
(0.134)\end{array}$ & u92 & $\begin{array}{c}0.6234^{* * *} \\
(0.221)\end{array}$ \\
\hline$u 18$ & $\begin{array}{c}-0.0851 \\
(0.403)\end{array}$ & $u 43$ & $\begin{array}{l}0.1405 \\
(0.237)\end{array}$ & $u 68$ & $\begin{array}{c}0.3372 * * \\
(0.131)\end{array}$ & u93 & $\begin{array}{c}0.6450 * * * \\
(0.235)\end{array}$ \\
\hline u19 & $\begin{array}{l}-0.0737 \\
(0.394)\end{array}$ & $u 44$ & $\begin{array}{c}0.1483 \\
(0.232)\end{array}$ & u69 & $\begin{array}{c}0.3458 * * * \\
(0.129)\end{array}$ & u94 & $\begin{array}{c}0.6691^{* * * *} \\
(0.252)\end{array}$ \\
\hline$u 20$ & $\begin{array}{c}-0.0626 \\
(0.386)\end{array}$ & $u 45$ & $\begin{array}{l}0.1560 \\
(0.227)\end{array}$ & $u 70$ & $\begin{array}{c}0.3545^{* * *} \\
(0.127)\end{array}$ & u95 & $\begin{array}{c}0.6966 * * \\
(0.272)\end{array}$ \\
\hline$u 21$ & $\begin{array}{l}-0.0518 \\
(0.378)\end{array}$ & $u 46$ & $\begin{array}{l}0.1637 \\
(0.222)\end{array}$ & $u 71$ & $\begin{array}{c}0.3633 * * * \\
(0.125)\end{array}$ & u96 & $\begin{array}{c}0.7289 * * \\
(0.295)\end{array}$ \\
\hline$u 22$ & $\begin{array}{c}-0.0414 \\
(0.370)\end{array}$ & $u 47$ & $\begin{array}{c}0.1714 \\
(0.217)\end{array}$ & $u 72$ & $\begin{array}{c}0.3723 * * * \\
(0.124)\end{array}$ & u97 & $\begin{array}{c}0.7686 * * \\
(0.324)\end{array}$ \\
\hline$u 23$ & $\begin{array}{r}-0.0312 \\
(0.362)\end{array}$ & $u 48$ & $\begin{array}{c}0.1791 \\
(0.212)\end{array}$ & $u 73$ & $\begin{array}{c}0.3815^{* * *} \\
(0.123)\end{array}$ & u98 & $\begin{array}{c}0.8214 * * \\
(0.364)\end{array}$ \\
\hline$u 24$ & $\begin{array}{l}-0.0213 \\
(0.355)\end{array}$ & $u 49$ & $\begin{array}{l}0.1867 \\
(0.207)\end{array}$ & $u 74$ & $\begin{array}{c}0.3908 * * * \\
(0.123)\end{array}$ & u99 & $\begin{array}{c}0.9047 * * \\
(0.427)\end{array}$ \\
\hline$u 25$ & $\begin{array}{c}-0.0116 \\
(0.347)\end{array}$ & $u 50$ & $\begin{array}{l}0.1944 \\
(0.202)\end{array}$ & $u 75$ & $\begin{array}{c}0.4003 * * * \\
(0.123)\end{array}$ & & \\
\hline
\end{tabular}

This table gives the estimated MTEs related to the choice of oil hedging maturity, long-term versus short-term. The MTEs are for firm value measured by the Tobin's $q$. $v_{\infty}$ reflects different estimation points of the unobserved resistance to use longterm hedging maturity. The superscripts $* * *,{ }^{* *}$, and * indicate statistical significance at the $1 \%, 5 \%$, and $10 \%$ levels, respectively. 


\section{B. Essential heterogeneity model}

Practically, essential heterogeneity models usually begin with a Mincer-like equation (Mincer, 1974), as follows:

$$
y_{i, t}=\alpha+\beta \times d_{i, t}+\sum \text { Control variables } \text { vat }-1_{1}+u_{i, t},
$$

where $y_{i, t}$ is the observed value of oil producer $i$ at the end of quarter $t$ and $d_{i, t}$ is the observed value of a dummy variable $D=(0,1)$ representing whether the oil producer $i$ uses short $(0)$ or long-term (1) hedging contracts at the end of quarter $t$. The control variables include the same set of observable covariates as presented previously, namely the return on assets, investment opportunities, quantity of oil reserves, oil production uncertainty, leverage ratio, liquidity, a dividend payout dummy, geographical diversification in oil production, institutional ownership, gas hedging ratio, gas reserves, and gas production uncertainty, oil and gas spot prices and volatilities, and a dummy variable for the years 2008 and 2009 respectively. The term $u_{i, t}$ is an individual-specific error term and $\beta$ represents the average return from using long-term hedging contracts.

Two sources of bias could affect the estimates of $\beta$. The first is related to the standard problem of selection bias, when $d_{i, t}$ is correlated with $u_{i, t}$, but it should be resolved using IV methods, among others. The second source of bias occurs if the returns to using long-term hedging positions vary across oil producers (i.e., $\beta$ is random), even after conditioning on observable characteristics leading to heterogeneous treatment effects. Moreover, oil producers make their hedging maturity choice (shortterm versus long-term maturity) with at least partial knowledge of the expected idiosyncratic gains from this decision (i.e., $\beta$ is correlated with $D$ ), leading to selection into treatment or sorting on the gain problem. 
Heckman, Urzua, and Vytlacil (2006) developed an econometric methodology based on IVs to solve the problem of essential heterogeneity (i.e., $\beta$ is correlated with $D$ ) in the estimation of MTEs. Their methodology is built on the generalized Roy model, which is an example of treatment effects models for economic policy evaluation. The generalized Roy model involves a joint estimation of an observed continuous outcome and its binary treatment, and is as follows. Let $\left(Y_{0}, Y_{1}\right)$ be the potential outcomes observed under the counterfactual states of treatment $\left(Y_{1}\right)$ and no treatment $\left(Y_{0}\right)$; these outcomes are supposed to depend linearly upon observed characteristics $X$ and unobservables $\left(U_{0}, U_{1}\right)$, as follows:

$$
\begin{aligned}
& Y_{1}=\alpha_{1}+\kappa+\beta_{1} X+U_{1}, \\
& Y_{0}=\alpha_{0}+\beta_{0} X+U_{0} .
\end{aligned}
$$

where $\kappa$ is the benefit related to the treatment $D=1$.

The selection process is represented by $I_{D}=\gamma Z-V$, which depends on the observed values of the $Z$ variables and an unobservable disturbance term $V$. The selection process, related to whether shortor long-term hedging positions are used, is linked to the observed outcome through the latent variable $I_{D}$, which gives the dummy variable $D$ representing the treatment status:

$$
D=\left\{\begin{array}{l}
1 \text { if } I_{D}>0 \\
0 \text { if } I_{D} \leq 0
\end{array}\right.
$$

where the vector of the observed values of the $Z$ variables includes IV variables $Z_{I V}$ and all the components of $X$ in the outcome equation. The variables $Z_{I V}$ satisfy the following constraints: $\operatorname{Cov}\left(Z_{I V}, U_{0}\right)=0, \operatorname{Cov}\left(Z_{I V}, U_{1}\right)=0$, and $\gamma \neq 0$. Our candidate IV $Z_{I V}$ is the change in the Kilian index. The unobservable set of $\left(U_{0}, U_{1}, V\right)$ is assumed to be statistically independent of $Z$, given $X$. We must 
first estimate the probability of participation in long-term horizon hedging maturities or the propensity score.

We can assume the joint normality of the unobservable components of the outcome and decision equations $\left(U_{0}, U_{1}, V\right) \sim N(0, \Sigma)$, where $\Sigma$ is the variance-covariance matrix of the three unobservables, with $\sigma_{1 V}=\operatorname{Cov}\left(U_{1}, V\right)$ and $\sigma_{0 V}=\operatorname{Cov}\left(U_{0}, V\right) . \sigma_{V V}=1$ following standard practice with the probit model. Under this parametric approach, the discrete choice model is a conventional probit with $V \sim$ $N(0,1)$, where the propensity score is given by:

$$
P(z)=\operatorname{Pr}(D=1 \mid Z=z)=\operatorname{Pr}(\gamma z>V)=\Phi(\gamma z)
$$

with $\Phi(\cdot)$ as the cumulative distribution of a standard normal variable. The term $P(z)$, called the probability of participation or propensity score, denotes the selection probability of using long-term hedging maturity conditional on $Z$ (i.e., $D=1$ ). Therefore we can write:

$$
\Phi(\gamma Z)>\Phi(V) \Leftrightarrow P(Z)>U_{D}
$$

where $U_{D}=\Phi(V)$ and $P(Z)=\Phi(\gamma Z)=\operatorname{Pr}(D=1 \mid Z)$.

The term $U_{D}$ is a uniformly distributed random variable between zero and one representing different quantiles of the unobserved component $V$ in the selection process. These two quantities, $P(Z)$ and $U_{D}$, play a crucial role in essential heterogeneity models. The quantity $P(Z)$ could be interpreted as the probability of going into treatment and $U_{D}$ is a measure of individual-specific resistance to undertake treatment or, alternatively, the propensity to not be treated. In our case, the higher the $P(Z)$, the more the oil producer is induced to use long-term hedging maturities because of $Z$. On the contrary, the higher the $U_{D}$, the greater the resistance of the oil producer to use long-term maturities due to a larger 
unobserved component. $P(Z)=U_{D}$ is thus the margin of indifference for oil producers that are indifferent between long- and short-term hedging horizons.

The marginal treatment effects (MTEs) can be defined as follows:

$$
\operatorname{MTE}\left(X=x, U_{D}=u_{D}\right)=\left(\alpha_{1}+\kappa-\alpha_{0}\right)+\left(\beta_{1}-\beta_{0}\right) x+\left(\sigma_{1 V}-\sigma_{0 V}\right) \Phi^{-1}\left(u_{D}\right) .
$$

In our application, estimation of the parameters follows the parametric method proposed by Brave and Walstrum (2014) by using the MARGTE command (See also Heckman, Urzua, and Vytlacil (2006b) for a description of the different estimation techniques that allow the computation of treatment effects in the context of essential heterogeneity models). Under the assumption of joint normality, $\sigma_{1 V}$ and $\sigma_{0 V}$ are the coefficients of the inverse Mills ratios. They are estimated separately along with the other parameters of the two following equations:

$$
\begin{gathered}
E(Y \mid X=x, D=1, P(Z)=p)=\alpha_{1}+\kappa+X \beta_{1}+\sigma_{1 V}\left(-\frac{\phi\left(\Phi^{-1}(p)\right)}{p}\right) \\
E(Y \mid X=x, D=0, P(Z)=p)=\alpha_{0}+X \beta_{0}+\sigma_{0 V}\left(\frac{\phi\left(\Phi^{-1}(p)\right)}{1-p}\right)
\end{gathered}
$$

to obtain the $\widehat{M T E}$ values, using the estimated propensity score:

$$
\widehat{\operatorname{MTE}}\left(X=x, U_{D}=u_{D}\right)=\widehat{\alpha_{1}+\kappa}-\widehat{\alpha_{0}}+\left(\widehat{\beta_{1}}+\widehat{\beta_{0}}\right) x^{\prime}+\left(\hat{\sigma}_{1 V}-\hat{\sigma}_{0 V}\right) \Phi^{-1}\left(u_{D}\right)
$$

Intuitively, how the MTE evolves over the range of $U_{D}$ informs us about the heterogeneity in treatment effects among oil producers, that is, how the coefficient $\beta$ is correlated with the treatment indicator $D$ in Eq. (B.1). Equivalently, the estimated MTE shows how the increment in the marginal firm value by going from choice 0 to choice 1 varies with different quantiles of the unobserved component $V$ in the choice equation. In our case, whether MTE increases or decreases with $U_{D}$ tells us 
whether the coefficient $\beta$ in Eq. (B.1) is negatively or positively correlated with the latent tendency of using long-term contracts for oil hedging. 